\title{
Çiftliks, Landed Elites, and Tax Allocation in Eighteenth-Century Ottoman Veroia
}

Yannis Spyropoulos, Stefanos Poulios and Antonis Anastasopoulos

\section{(2) OpenEdition}

\section{Journals}

Electronic version

URL: http://journals.openedition.org/ejts/6647

DOI: $10.4000 /$ ejts. 6647

ISSN: $1773-0546$

Publisher

EJTS

Electronic reference

Yannis Spyropoulos, Stefanos Poulios and Antonis Anastasopoulos, «Çiftliks, Landed Elites, and Tax Allocation in Eighteenth-Century Ottoman Veroia », European Journal of Turkish Studies [Online], Complete List, Online since 21 December 2020, connection on 26 December 2020. URL : http:// journals.openedition.org/ejts/6647 ; DOI : https://doi.org/10.4000/ejts.6647

This text was automatically generated on 26 December 2020.

(c) Some rights reserved / Creative Commons license 


\title{
Çiftliks, Landed Elites, and Tax Allocation in Eighteenth-Century Ottoman Veroia
}

\author{
Yannis Spyropoulos, Stefanos Poulios and Antonis Anastasopoulos
}

The project from which this paper emanates has been implemented through the Operational Programme 'Human Resources Development, Education and Lifelong Learning' of the Hellenic Republic and co-financed by the European Union (European Social Fund) and Greek national funds. The project has been carried out at the University of Crete.

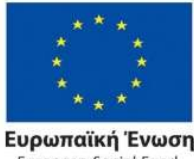

Eupwraïkń 'Evwơn
European Social Fund
Operational Programme

Human Resources Development,

Education and Lifelong Learning

Co-financed by Greece and the European Union
EЕПА

프밀 2014-2020

1 This article revolves around three intertwined institutions in the eighteenth-century Ottoman Balkans, namely the ayan, çiftliks, and taxation. Ayan was the collective designation of the Muslim elite who lived in the Ottoman provinces. Their rural landholdings were known as çiftliks in juxtaposition with land that was held by smallholder peasants; as Bruce McGowan has succinctly pointed out, çiftliks in this sense means "a unit of indeterminate size whereby the essential thing implied was ownership (or at least entitlement) by one party [i.e., the çiftlik holder] and actual production by others [i.e., the peasants]" (McGowan 1994: 681). The apportionment and collection of taxes and other communal expenses in documents known as tevzi defterleri (registers of apportionment; hereafter, tevzi registers) was an instance of negotiation among local actors, among whom the ayan were prominent, wherein the status of the soil-under elite or peasant control-played an important part.

2 Earlier scholarship has shown the importance of çiftliks for the financial and political empowerment of the ayan as one of several investment options available to them, and has pointed out both the registration of çiftliks in tevzi registers and the usefulness of the latter for the study of the proliferation of çiftliks, or chiftlicisation (McGowan 1981: 
73-79, 157-170; Neumann 1987/88: 17-27; Ursinus 1995: 348-359; Anastasopoulos 1999: 28-35; Kotzageorgis, Papastamatiou 2014; Kokdas 2014: 141, 143-144; Anastasopoulos, Gara 2015: 275-277, 280-286; Papastamatiou 2017). Ayan empowerment took place in the course of the eighteenth century in a political setting which was favourable to them because of the relative, or even total, absence of central state representation in many provinces. In their capacities as the leadership and representatives of their districts, the ayan were used by the state to provide services in fields such as tax collection, the maintenance of public order, and the recruitment of soldiers and dispatch of ammunition and provisions to the army in wartime. A few ayan rose to great power, even occupying state offices and obtaining control over huge territories. But most were middle and small-scale notables vying with competitors for control over local or regional resources (İnalc1k 1977; McGowan 1994: 642, 644, 658-679; Anastasopoulos 2015; Yaycioglu 2016). Tax-farming was the prevalent mode of tax collection in the eighteenth century, and that led to the building of networks of contractors and subcontractors with Istanbul as the starting-point and often local ayan as the actual tax collectors at the other end, i.e., the local level. Participation in such networks was another springboard for the political and financial empowerment of the ayan, while tax-related peasant indebtedness to them as creditors or tax farmers is considered a factor which led to the transfer of peasant rights over agricultural land to the local elite (Salzmann 1993; McGowan 1994: 661-662; Ursinus 2012: 425, 431-433; Kokdas 2014: 137, 142; Yaycioglu 2016: 77-78, 96).

3 This article focuses on the judicial-administrative district (kaza) of Veroia (Ott. Karaferye; today in Greece, Region of Central Macedonia), which as early as 1981 McGowan counted among the "districts with a larger share of chiftliks" or "heavily chiftlicized zones" (McGowan 1981: 75, 94). The district of Veroia bordered on that of Thessaloniki (Ott. Selânik) lying to its west and combined a mountainous western and southern part with an extensive plain and access to the sea on its eastern side (Fig. 1). In an earlier article (Anastasopoulos et al. 2019), we used the evidence of tevzi registers in order to argue that indeed the eighteenth century was crucial for the spread of çiftliks in the kaza of Veroia, and that, as a result, rural land progressively came under the control of an almost exclusively male, Muslim elite. In this article, we demonstrate how chiftlicisation impacted the methodology of compilation of the tevzi registers and thus tax distribution among the local population, and discuss the case of one of the major local landholding families, pointing to the fluctuation of their rural landed property over time. As in our earlier article, we are interested in peasant dispossession of their lands in favour of the establishment and spread of çiftliks and relate this phenomenon to the way in which tax distribution was made. To do so, we embark on a detailed analysis of tevzi registers that demonstrates the existence, at specific points in time, of parallel but distinct changes in the principles and methodology according to which different series of tevzi registers for different taxes and other communal expenses were compiled; it is assumed that the ayan played an important part in this process in their capacity as local landholders who sought to negotiate the best possible terms of taxation for their investments and dependent peasants. Then, we delve deeper into the value of tevzi registers as a source for the study of the spread and eventual domination of çiftliks in the rural economy of Veroia and we exemplify the changing methodology of compiling these registers as discussed in the first part of the article by providing a survey of landownership at the micro-historical level through the case of an eminent ayan family, the Sarıcazades. 


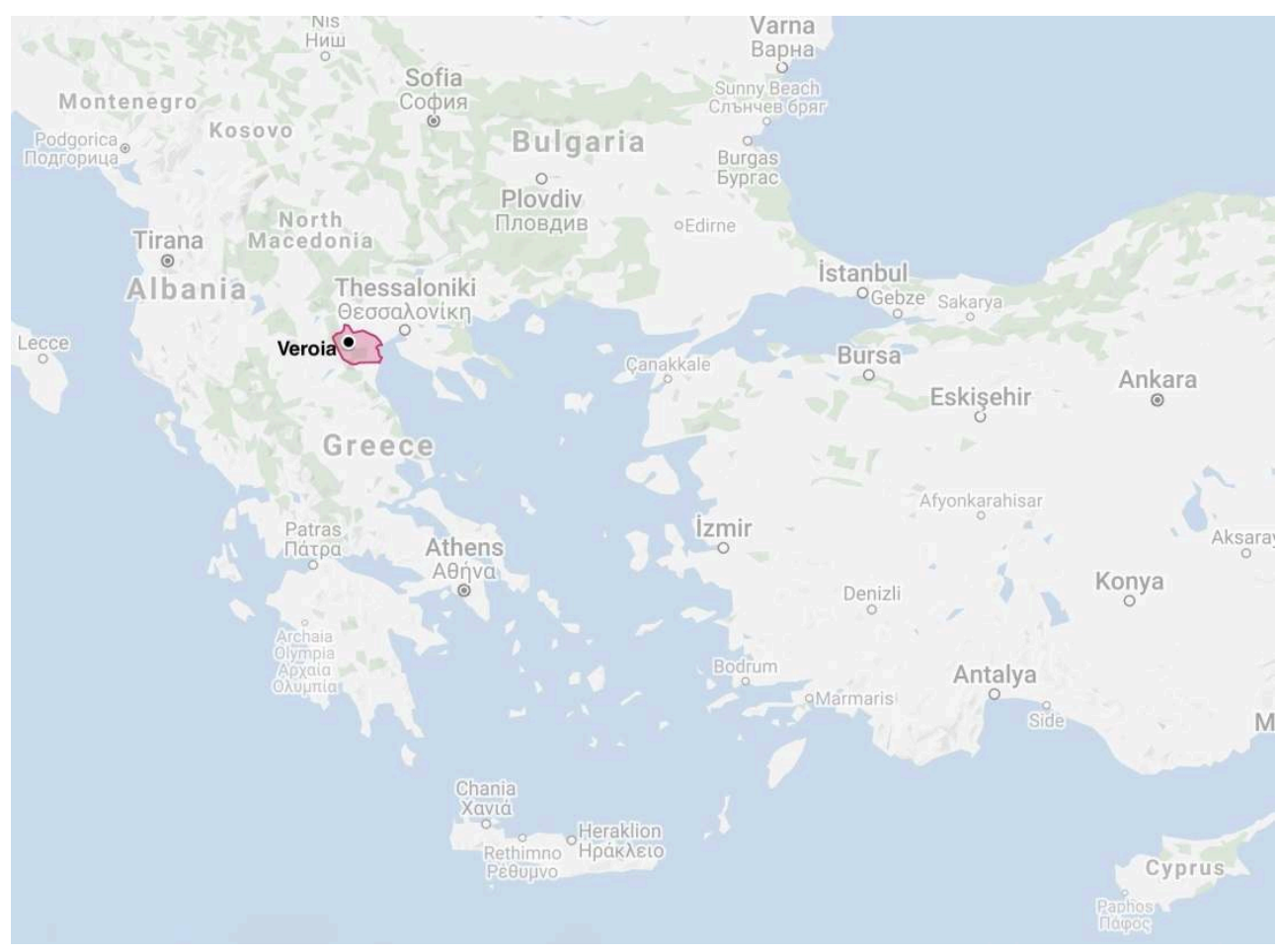

Figure 1: Approximative borders of the judicial-administrative district (kaza) of Veroia in the eighteenth century.

(Map data (C)2020 Google)

4 There is abundant literature about çiftliks, a term that was used to describe several forms of rural landholding over the centuries. An article by Gilles Veinstein, published in 1991, reviewed earlier research (e.g., McGowan 1981; İnalcık 1991) on what he called the "çiftlik debate", and provided an authoritative account of the emergence and internal workings of çiftliks as we have defined them above (Veinstein 1991). Veinstein himself described the çiftlik as "an extensive arable holding" but also remarked that "they [çiftliks] were not invariably, or even predominantly, the sizeable estates they were generally assumed to be" (Veinstein 1991: 35, 48). He dismissed the Marxist theory that interpreted çiftliks as an aspect of the transition from feudalism to capitalism, the attribution of the rise of çiftliks to the needs of international markets for cereals and cotton, according to the 'second serfdom' and 'peripheralisation' theories, as well as the treatment of çiftliks by the 'Ottomanist' theory as the products of an illegal process of private appropriation of agricultural land which under the terms of the 'classic' Ottoman system should have belonged to the state. Veinstein pointed out that çiftliks were formed by both legal and illegal means; that political, economic, and social developments within the Ottoman realm suffice to explain their emergence; that the establishment of a çiftlik by a private individual could take place on land abandoned by the local peasants, but when the original cultivators remained in place, they were subjected to extra payments to the çiftlik holder in addition to those made to the state and its local appointees in the context of the timar system; that çiftliks were not intensively cultivated nor were they market-orientated in a capitalist manner for lack of such a mentality; and that sharecropping was the dominant arrangement between çiftlik holders and those who cultivated the soil or herded livestock.

More recent research has confirmed the arguments and assumptions that Veinstein made on scanty evidence. From among those who have worked on the eighteenth- 
century Balkans, Sophia Laiou has shown that çiftliks in western Thessaly were formed legitimately on both private and state land; that in the latter case peasants had to bear the extra burden of making payments not only to the timar holder whom the state had appointed as the rightful recipient of dues but also to the çiftlik holder who occupied a place in between the peasants and the timar holder; and that long-term tax-collection rights could lead to de facto rights of ownership over an area (Laiou 2007: 268-270, 274-276). İrfan Kokdaş has argued that sharecropping, patronage, and credit relations formed a triangle that pervaded urban elite-peasant relations in the context of chiftlicisation; that the protection that landholders could provide against taxation and outlaws was an incentive for peasants to abandon their villages and settle on çiftliks; and that çiftlik-holding translated into political capital (Kokdas 2014). Based on probate inventories from Thessaloniki, Phokion Kotzageorgis and Demetrios Papastamatiou have confirmed that landholding and being owed amounts of money (most likely from moneylending) were two assets which typically were combined in the properties of the wealthy, while Papastamatiou has demonstrated that çiftliks were owned mostly by a military-dominated elite of wealthy Thessalonians, and were low-investment and intensity productive units whose production was nevertheless intended for the market (Kotzageorgis, Papastamatiou 2014: 171-178; Papastamatiou 2014; Papastamatiou 2017: 225-231). Finally, Fatma Öncel has discussed the competition between absentee legal owners of land rights and local çiftlik holders over land and peasants as well as the multiplicity of payments to which peasants were subjected as a result of the Ottoman tax-farming system and the various institutions and persons with claims on land and its revenues (Öncel 2017).

6 Tevzi registers were compiled for various taxes and communal expenses at regular intervals or whenever it was necessary to do so. They were entered in the kadl sicilleri, i.e., the registers of the local court of law, and, as noted above, are considered to be the products of negotiation among local land and power holders and community representatives; as such they constituted a decentralised, local, self-regulated procedure of allotment of tax obligations and other communal expenses. The eighteenth-century tevzi registers of Veroia were typically composed of an introductory part where it was explained which tax or expenses and which period of time they concerned; when they concerned communal expenses, a detailed list of them, their grand total and its distribution among groups of settlements (for the most part of the eighteenth century, the Christians of the town and the kaza's villages, the latter being listed either as one or more groups dependent on their fiscal status); and a third part where it was recorded what the share of each village was. Village shares were entered under the names of those individuals who held control of the land as çiftlik holders or the local villagers collectively. ${ }^{1}$

7 The tevzi registers of Veroia allow us to visualise the spread of çiftliks in the district (Figs. 2-4). According to them, the formation of çiftliks seems to have started in the late seventeenth century from the villages to the north and east of the town of Veroia, that is, in the area between this town and the smaller town of Naousa (Ott. Ağustos) and in the plain between Veroia and Thessaloniki. Chiftlicisation later expanded to villages further away from the town, and by the end of the eighteenth century there was a small number of villages which had not become or did not include çiftliks. The mountainous or more distant villages seem to have been either the last to be transformed into çiftliks or those which were never chiftlicised. The exact relationship 
between the spread of çiftliks, commercialisation of agriculture, and geography is a topic that awaits further research. ${ }^{2}$

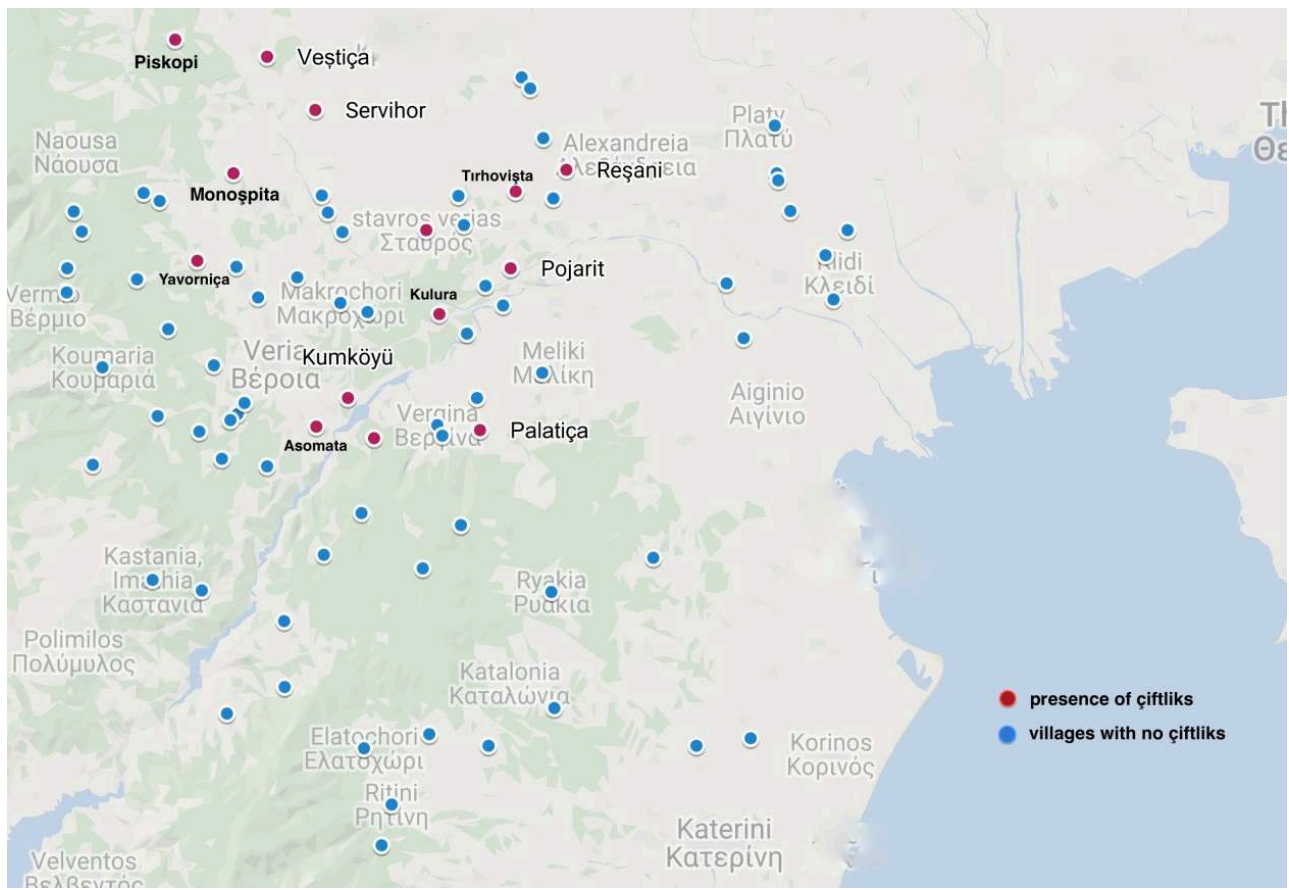

FIgURE 2: Villages with and without çiftliks in the district of Veroia in 1701 according to tevzi registers. (Map data (C2019 Google)

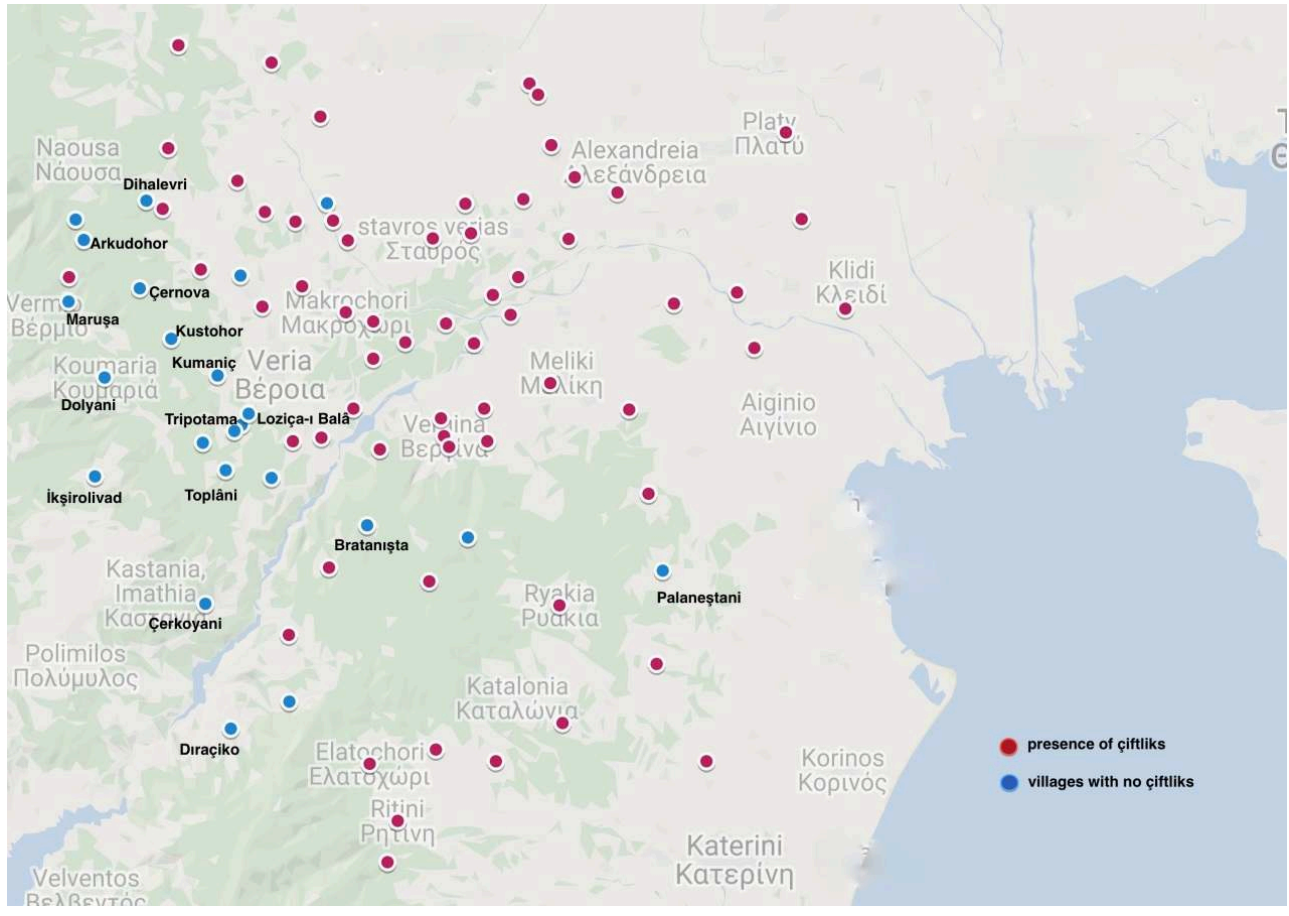

FIgURE 3: Villages with and without çiftliks in the district of Veroia in 1751 according to tevzi registers. (Map data ()2019 Google) 


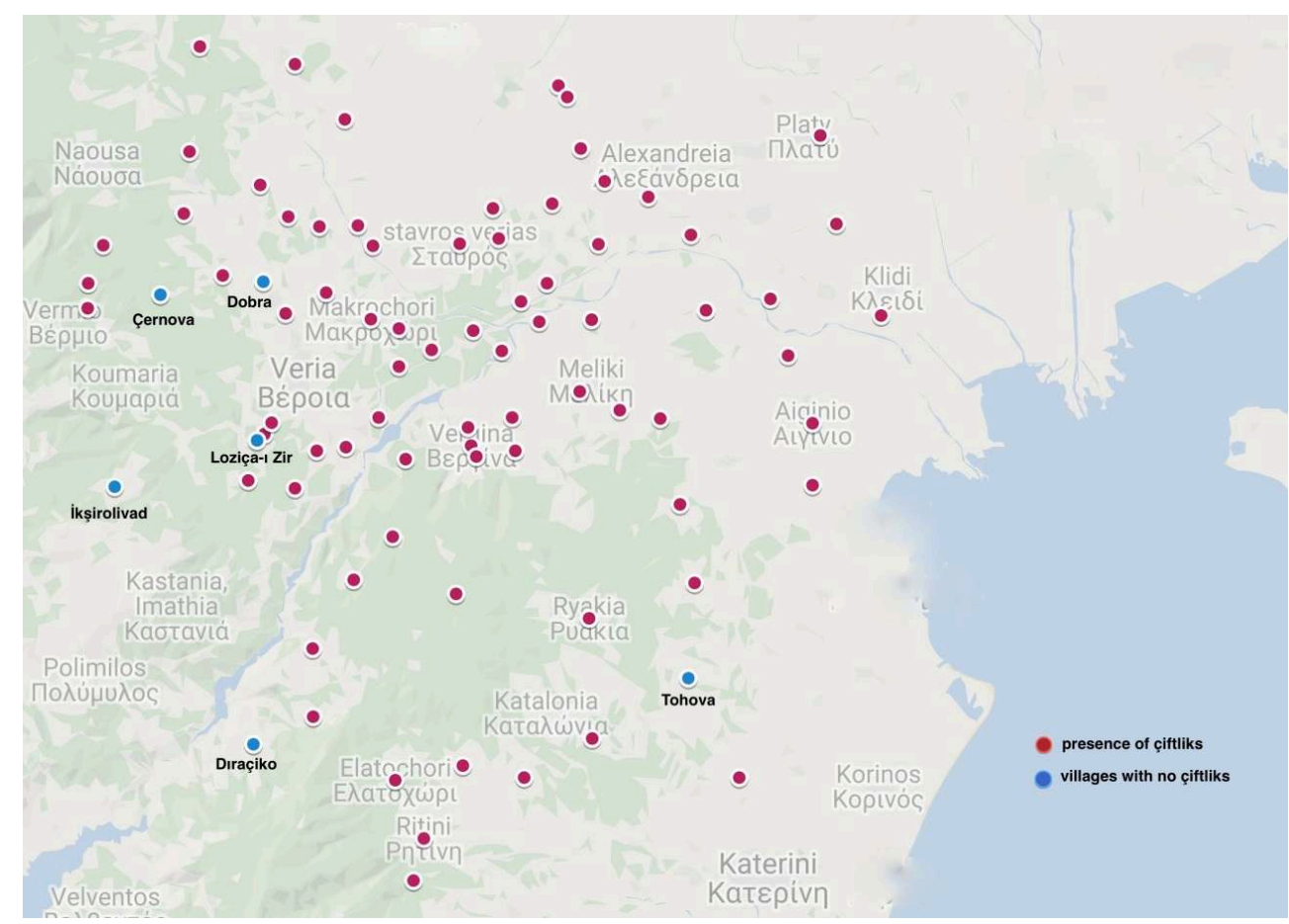

FIgURE 4: Villages with and without çiftliks in the district of Veroia in 1795 according to tevzi registers. It must be noted that although Tohova appears in KKS-GR 101/9-12, 25 Zilhicce 1209 / 13 June 1795, as the only non-chiftlicised village east of the town of Veroia, it was recorded as an estate of the family of Hasan Ağa from as early as the first half of the eighteenth century. In general, only about three to nine villages appear as non-chiftlicised in tevzi registers at around the turn of the nineteenth century; see, for instance, KKS-TRa 1091/9 and 13-14, 25 Zilhicce 1207 / 3 August 1793 and 22 Receb 1207 / 5 March 1793, respectively; KKS-TRa 1092/3, 27 Rebiülahır 1215/ 17 September 1800. It is also to be noted that in the late eighteenth century, many villages of the district of Veroia were bundled together anonymously in the tax shares of their landholders in the alâka format, about which see below. Therefore, the map is an indicative rather than accurate depiction of chiftlicised and nonchiftlicised villages.

(Map data (2) 2019 Google)

\section{Chiftlicisation and the Tevzi Registers of Veroia}

8 The function, set-up, and content of the tevzi registers of Veroia underwent a series of drastic changes in the course of the late seventeenth and eighteenth centuries. For the most part of this period, not only did their presence in the kadı court registers become increasingly dense, but also their structure became more complex, both in the description of the various taxes and other communal expenses which they included and in the way that those were allocated to the local population. As we will explain, one of the most important factors which contributed to these changes was the aggressive expansion of çiftlik properties in the area. ${ }^{3}$

The categories of tevzi registers that we find in the records of the kadı court of Veroia from the late seventeenth, eighteenth, and early nineteenth centuries pertain to the apportionment of various local expenses (masarif-i vilâyet), the poll tax for the nonMuslims (cizye), the sheep tax (adet-i ağnam), as well as some extra-ordinary-often in name rather than in essence-provisions in cash or kind, such as the avariz/nüzül taxes and the saltpetre and grain-related levies (güherçile, mubayaa, and sürsat). of all these types of apportionment registers, the ones that have the greatest value for the examination of the chiftlicisation process in Veroia are the masarif-i vilâyet, the avarı/ 
nüzül and the mubayaa. This is not only because of the frequency with which they appear during the eighteenth century, ${ }^{4}$ but also owing to the unique way in which they document landed-estate-related proprietary changes in the region. Furthermore, their examination provides one comparative advantage: the masarif-i vilayet were mostly levies collected for communal expenses which had been incurred locally, while avariz/ nüzül and mubayaa were taxes destined for Istanbul and their rates (avarı/nüzül) or quantities (mubayaa) were determined by the central government. Thus, our focus on these three categories of tevzi registers gives us the opportunity to trace how state intervention, or lack thereof, influenced the process of documenting the presence of çiftliks and what kinds of opportunities it created for the local landed elite to promote its economic interests in the region.

10 Before the last decade of the seventeenth century the allocation of the various categories of taxes and local expenses mentioned above was recorded in a quite homogeneous fashion in all the types of tevzi registers: first, any areas and/or taxpayer categories whose contribution was paid in a lump sum-the most common among them being the Muslim, Christian, and Jewish communities of the town of Veroia, the monks of the monasteries of the kaza, villages belonging to the Sultanic hasses (havass) and vakıfs, and two further groups of villages, the Tuzcıyan and Menlikân ${ }^{5}$-were listed along with the sums which they had to pay on each occasion. Following these lumpsum entries, all the other tax-paying rural settlements of the kaza, chiftlicised and nonchiftlicised alike, were listed in a single, long list (Facsimile 1). In this primitive form of tevzi registers, the existence of çiftliks, when indicated, was recorded by means of a short note above the name of the village where they were situated ("çiftlik of so-and-so village"). These references are useful for the study of the spread of large landownership in the area, but they are too laconic to allow the drawing of more comprehensive conclusions about it.

11 As çiftlik ownership in the region advanced, however, this format gave way to another that was more attentive to the chiftlicisation process and recorded it in much more detail: sometime between 1687 and 1696 the villages in many tevzi registers started to be recorded in two separate lists, one containing çiftliks and the other consisting of non-chiftlicised villages (Facsimile 2). ${ }^{6}$ For one or two decades these bipartite registers co-existed with the old single-category ones, the recording of which became increasingly scarce and eventually obsolete in 1707.7

12 The new bipartite registers did not provide any information other than whether a village was çiftlik or not, but this was to change drastically between the end of the seventeenth century and the 1730s. Changes are observed first in tevzi registers for avariz and nüzül, cash taxes that were collected together for the treasury (McGowan 1981: 108-110). The collection of these taxes was carried out by agents appointed by the state (Inalc1k 1980: 316-317, 335-336), but it is unclear if they participated themselves in the process of compilation of the tevzi registers for avariz and nüzül. If they did, it is possible to argue that it was the state which induced the changes that we describe below as it became increasingly aware of the new reality of çiftliks. Otherwise, the changes may have been a local initiative which sought to reconcile the spread of çiftliks with the terms of collection of taxes whose rate was fixed by the state rather than being determined locally as happened with other kinds of communal expenses collected through tevzi registers. At any rate, the persistence of the old tax unit of hane $e^{8}$ in the tevzi registers for avariz and nüzül at a time when the compilers of tevzi registers for 
other types of expenses experimented with other names for tax shares must have emanated from the fact that this was the tax unit used in the decrees which arrived in Veroia for the collection of these two taxes. Two more observations suggest that the fact that the process of collection of avariz and nüzül was initiated by the state was the decisive factor that led to the revision of the format of the tevzi registers about them. One is that the structural changes which we describe below are not to be observed in the tevzi registers of Veroia which concerned expenses unrelated to the central state, such as the masarif-i vilâyet. The other is that it is only the tevzi registers for avariz and nüzül that record a third type of land status, namely mezraas. The term 'mezraa', whose roots lay in Sultanic legislation about the timariot system, described miri arable lands within abandoned villages or beyond the boundaries of villages (Moutafchieva 1988: 33-37; Inalc1k 1991: 22-23). One may thus argue that mezraas existed only in the eyes of the central administration and that, consequently, they were imposed from above on the local elite of Veroia, who were obliged to take this land category into consideration when distributing the avarız and nüzül taxes among the settlements of Veroia. Nevertheless, it is not clear why this third category of land status was introduced in the tevzi registers in 1732 and not earlier. Although there have been studies examining the regional differences between masarif-i vilâyet bookkeeping practices (Ursinus 1995), to our knowledge there are no such studies for avarız and nüzül, whose process of collection has been examined mostly in reference to the seventeenth century, that is, at a time that antedates the widespread use of tevzi registers (Öztürk 1997; Demirci 2010; Çakır 2010). ${ }^{9}$ As a result, it is difficult to draw definite conclusions as to precisely what triggered a more detailed recording of the tax shares of the çiftliks only as opposed to 'independent' villages, as we will explain below.

13 In any case, what we observe at a first stage is that some fragmentary tevzi registers of the 1690s onwards for avarız and nüzül indexed not only Veroia's çiftliks but also their owners. ${ }^{10}$ Then, in 1704 a new type of tevzi register for avarız and nüzül emerges. ${ }^{11}$ These new tevzi registers went a step further from their bipartite predecessors in that not only did they make a clear distinction between chiftlicised (kura/haneha-yı çiftlikân) and non-chiftlicised (kura/haneha-yı reaya) ${ }^{12}$ villages, but they also specified how many çiftliks were located inside the boundaries of each village, who their owners were, and, from a certain point onwards, how the labour force and means of production were distributed within such properties.

14 More specifically, although in the new tevzi registers for avarız and nüzül the section of non-chiftlicised villages remained unchanged, in the section of their chiftlicised counterparts each village entry recorded individually the çiftliks that existed in the village together with the names of their owners. These more elaborate çiftlik-village entries continued, as noted above, to calculate fiscal shares in hanes, but from around $1735^{13}$ they started to break down the hanes of çiftliks into two distinct fiscal sub-units, 'landless peasants' (haymane) ${ }^{14}$ and means of production or 'pairs of oxen' (çift), ${ }^{15}$ separating one from the other. The tax shares of non-chiftlicised villages, on the other hand, continued to be calculated in the traditional way: The peasants and their 'oxen' were registered as one inseparable unit, based on the old avarız/nüzül hane. ${ }^{16}$ In this framework, one independent reaya peasant (with a 'pair of oxen', i.e., their means of production) was calculated at 0.4 of a hane. In a chiftlicised village, however, the value of one haymane peasant, having now been deprived of the ownership of the means of production (çift), was calculated at just 0.166 of a hane, while one çift was calculated as having a value of 0.5 hanes. In other words, according to the reformed avarı/nüzül- 
register accounting, one hane included either 2.5 independent peasants with their 'oxen', 6 çiftlik-dependent peasants without 'oxen', or 1.5 çiftlik-dependent peasants with 'oxen'. ${ }^{17}$

At a first glance, this recalculation seems to have worked in favour of the çiftlikdependent peasants. It is, after all, plausible to assume that the accounting separation of the latter from the 'pairs of oxen' that they used for the cultivation of çiftliks expressed an attempt on the part of those who negotiated the allocation of taxes to alleviate them of an extra burden. However, given the lack of any information concerning the rationale behind this reform, we cannot be sure if other interests were at play or how these new measures impacted the various other contributions which çiftlik holders collected from dependent peasants and are not to be found in the tevzi registers. ${ }^{18}$ After all, even if we accept that the figures of these tax units were an accurate reflection of the peasant/'oxen' ratio within çiftliks, the vague ownershipdetached from the peasants for accounting purposes, yet attributed to no one in particular-of the çiftlik 'oxen' seems as a trait that could have been the subject of manipulation by large estate owners during the tax-collection process. ${ }^{19}$

One of the most surprising aspects of this reform is that less than a decade after the tevzi registers for avarı and nüzül reached their most elaborate form, they became static: from 1744 and for the next 33 years, until 1777, the lists of villages of the two categories, 'independent' and çiftlik, froze despite the fact that the data provided by the tevzi registers for masarif-i vilâyet or mubayaa point to expanding chiftlicisation of Veroia's rural periphery (Chart 1 ).

Chart 1: Comparison between the number of non-chiftlicised villages listed in tevzi registers for avarız and nüzül, masarif-i vilâyet, and mubayaa in the years 1735-1785.

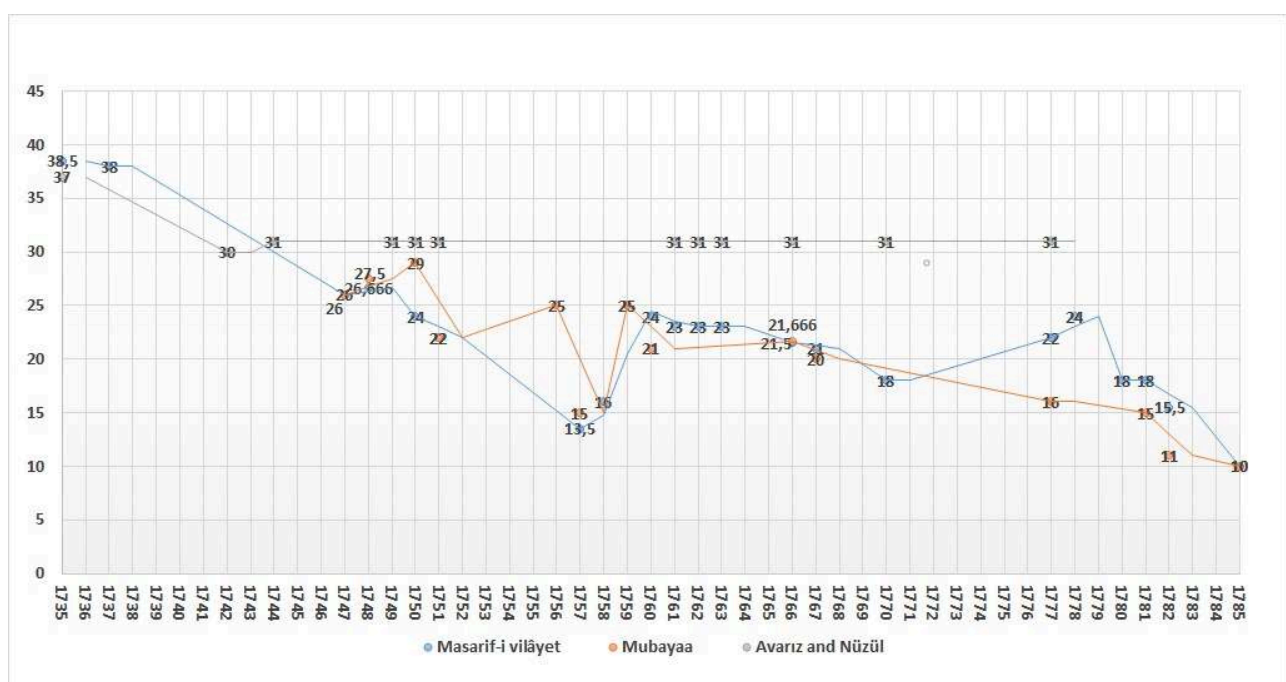

The freezing of the data of the tevzi registers for avarı and nüzül may be explained by the lack of new censuses of taxpayers on the part of the Ottoman state in combination with the insignificance into which the two taxes fell in the course of the eighteenth century (McGowan 1981: 113-114, 118, 157; Sahillioğlu 1991: 109; Cezar 1996: 94). If the official number of hanes charged with these taxes remained more or less stable for a large part of the eighteenth century and the burden that these taxes represented for the local population declined, maybe there was no need for the tevzi registers for avariz and nüzül to be updated or adjusted. It is to be noted that 1777 marks in fact the last 
year from which we have been able to find a tevzi register for these two taxes in the kadı court records of Veroia. ${ }^{20}$

In direct contrast to the freezing and decline of the tevzi registers for avarız and nüzül in the years 1744-1777, not only was the number of tevzi registers for masarif-i vilâyet on the rise throughout this period, but their content also became increasingly elaborate and responsive to even the smallest proprietary changes in the region, thus providing invaluable information on the chiftlicisation process in Veroia.

19 In 1746, the format of the tevzi registers for masarif-i vilâyet also changed; ${ }^{21}$ we do not know what triggered this change, but they, too, lost their bipartite structure and adopted one that was closer to that of the new registers for avarı and nüzül (Facsimile 3). Despite the superficial resemblance, however, the new masarif-i vilâyet registers were different from the avarı/nüzül registers in several ways. First, as noted above, they did not contain mezraas. Second, they started for the first time to break down the village groups of the Tuzciyan, Menlikân, and havass (for which up to then only a lump sum was entered in the registers) into the individual settlements that they included and ascribe to each of them a fiscal share labelled rakam. From non-tevzi entries we know that çiftliks had existed in these areas for more than two decades before this change, ${ }^{22}$ which represented an overt recognition of the spread of this type of property within these special-status fiscal districts, too, as their villages were now listed in two separate lists, one for the chiftlicised and another for the 'independent' ones. As we shall see, this would only be the first step towards the future accounting assimilation of these areas into the 'common' village lists of the tevzi registers. Third, although, in their 'çiftlikân' section, the new masarif-i vilâyet registers recorded the name of each çiftlik holder and even initially calculated tax shares in the units used in the tevzi registers for avariz and nüzül, it is clear that their purpose was by no means to create a detailed account of dependent peasants and means of production within çiftliks. For example, although the kura/haneha-yı çiftlikân section of the 1746 masarif register made use of the haymane unit, it did so with no reference whatsoever to çifts. In the years which followed, the same pattern would continue to exist, but with different units expressing tax shares. In 1748, a new unit, re's (literally meaning 'head'), ${ }^{23}$ was introduced in place of haymane and continued to be in use until 1761, when çift started being used interchangeably with re's as the unit in which shares were calculated; a comparison between various masarif-i vilâyet registers proves that both represented the same unit and, thus, that in this context çift did not denote 'means of production'. ${ }^{24}$ Subsequently, as of 1766 , only the term çift was used, until sometime between 1770 and 1777, when re's became the standard term for the calculation of the tax shares of çiftliks and continued to be so at least until 1815.

It is obvious that for 30 years or so the local actors involved in the apportionment of communal expenses among the population of Veroia experimented with the terms which would describe the tax-yielding capacity of çiftliks against that of 'independent' villages, whose tax shares continued to be counted in hanes until the late 1750s. It seems that, at a time when the 'gold standard' of all tevzi apportionments, the avariz/ nüzül hane, was waning, initiatives were taken at the local level for its replacement. ${ }^{25}$ This experimentation was, however, much more profound than the recasting of units; it was, first and foremost, about the creation of an accounting matrix which reflected the rising economic power of the landed elite of Veroia: çiftliks were rapidly becoming the dominant type of agricultural property in the region (Charts 2 and 3, and Figs. 2-4) 
and, thus, the gauging of the tax-yielding capacity of any other type of landholding had to conform to the standards set by their holders.

Chart 2: Number of non-chiftlicised villages according to tevzi registers of Veroia from 1696 to $1815 .^{26}$

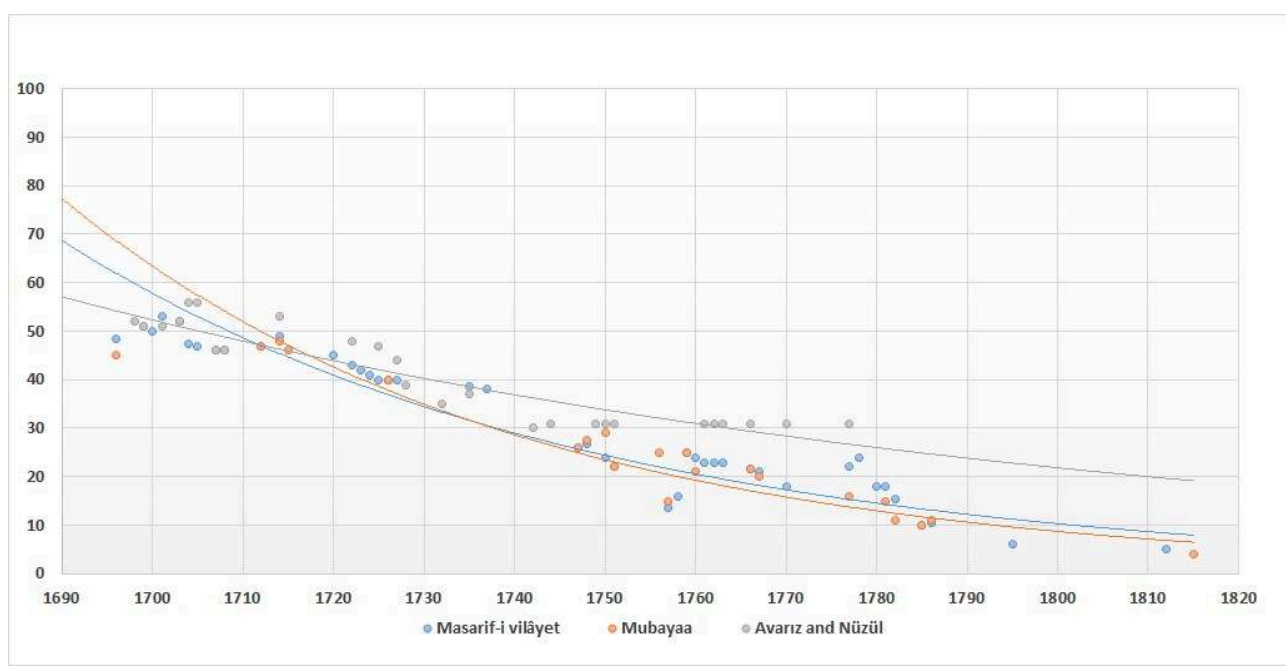

Chart 3: Çiftlik to independent-village tax-share ratios (in hane or re's) according to six tevzi registers for masarif-i vilâyet from 1701 to 1812 .

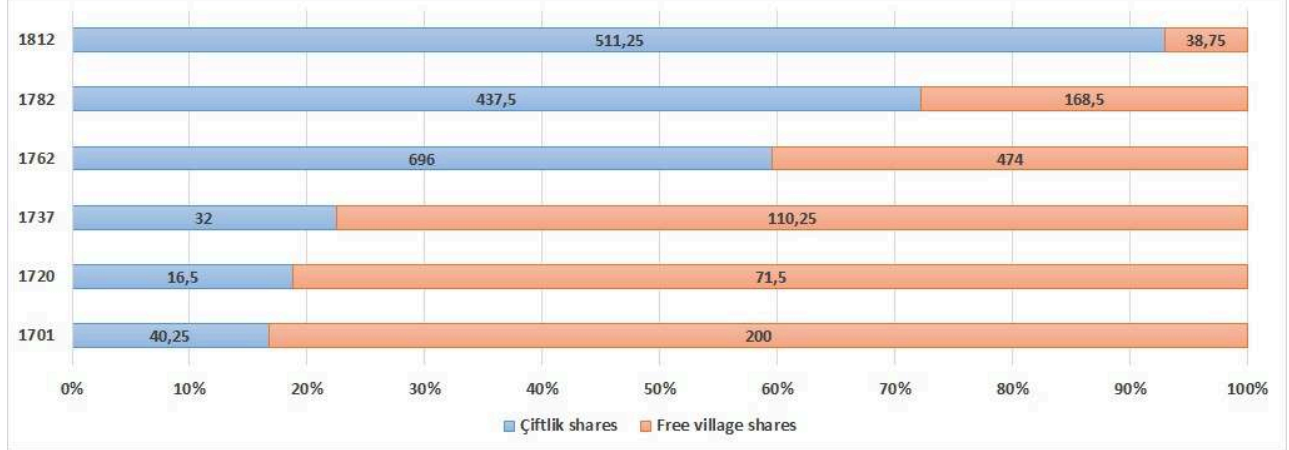

21 This becomes more evident from 1758 onwards, when a process of homogenisation of the tevzi registers for masarif-i vilâyet was initiated (Facsimile 4). In that year, most internal groupings of the villages of the district of Veroia (Tuzcıyan, Menlikân, çiftlikân, kura- $\iota$ reaya, etc.) which had been used up to that point were abolished and all settlements started being listed in a single, undifferentiated, list, as had been the case until more than half a century earlier. ${ }^{27}$ Yet, in contrast with the independent-villageorientated single-list tevzi registers of the late seventeenth century, this time all the accounting features of the registers revolved around the landholding form of çiftlik: first of all, all villages, regardless of their status-chiftlicised, belonging to a special fiscal category, or otherwise-were listed together as 'çiftliks', a term that replaced 'karye', the tag that had been used up to then for 'independent' villages. Similarly, the use of hane, the tax unit used for 'independent' villages, ceased; it was replaced by the units that were used for the çiftliks, i.e. çift or re's.

Another interesting feature which first appeared in 1746 was the lumping together into distinct items-first called 'çiftlikân', then, in 1748, 'emlâk', and ultimately, from 1758 onwards, 'alâka'28 - of various chiftlicised villages under the names of particular 
individuals (Facsimile 3-4). The alâkas, which were placed right under the village list proper of each tevzi register, became in the years which followed one of the most characteristic traits of the tevzi registers for masarif-i vilâyet; they expressed the adaptation of provincial tax collection to the expanding control of the local elite over rural land, by bringing the biggest landowners of Veroia to its very centre. It is the landownership of these individuals which gradually became the main gauge for the allocation of taxes and other communal expenses among the villages of the entire kaza. Suffice it to say that while a tevzi register of 1758 included the landholdings of only three individuals in the form of alâkas, representing 12.13 per cent of tax shares in the $k a z a,{ }^{29}$ the number of alâkas had risen to 15 by 1795 and 17 by 1802, representing an overwhelming 76.5 and 83.6 per cent of the allocated tax shares, respectively. ${ }^{30}$

23 A third category of tevzi registers-apart from those for avarı/nüzül and masarif-i vilâyet -is the one that concerns mubayaa, or the compulsory sale of grain to the state for the needs of Istanbul. In 1747, three years after the freezing of the fiscal data of the tevzi registers for avarız and nüzül, the tevzi registers for mubayaa started to follow a trajectory that was strikingly close-both in terms of data and format-to that of the registers for masarif-i vilâyet, which, in turn, had started moving away from the village numbers and units of tax assessment used in the avariz/nüzül registers.

Rarely found in judicial records and following a bipartite structure until 1747, the mubayaa registers became one of the most regularly used tax-related entries of the kadl court records of Veroia from that year on, which may be reasonably attributed to the fact that as of 1748 the Ottoman central administration started to systematically control the quotas of grain which were to be sent by each province (Aynural 2002: 5-6). Although one may spot differences in the numbers of villages listed in tevzi registers for mubayaa and those for masarif-i vilâyet, the figures they record follow very similar trend lines. Furthermore, they both use the same units for the tax shares of the kaza's settlements, they start recording the alâkas of çiftlik holders at around the same time, and undergo the shift to single-category çiftlik-centred bookkeeping together. ${ }^{31}$

When we take into account the differences which we have discussed between the tevzi registers for local expenses (masarif-i vilayyet) and those for the state-imposed avarı and nüzül, it may seem difficult to explain the parallel trajectory between the tevzi registers for another state imposition, namely mubayaa, and those for masarif-i vilâyet. Maybe the answer lies in the fact that the quotas for avariz and nüzül were based on registers which were kept at the imperial treasury, ${ }^{32}$ which divided the Empire's taxpaying subjects into three categories-high, medium, and low class-corresponding to different wealth levels (Barkan 1949: 15; Demirci 2010: 45). The calculation of households was undertaken locally, and detailed lists were sent to Istanbul for inspection and processing, which, in turn, led to the creation of detailed registers pertinent to most provinces of the Empire (McGowan 1981: 111-112, 118-120; Akyüz Orat 2012: 223-224). As noted above, the procedure of tax collection involved the dispatching from the capital of an agent who bore a sealed copy of a mevkufat register listing the hanes of the area and a ferman specifying the name of the tax collector, the year to which it pertained, the number of taxpaying hanes, and the amount to be collected (Cvetkova 1959: 61-62; McGowan 1981: 161-162). ${ }^{33}$ In other words, avariz and nüzül represented a tradition of state-imposed taxes whose process of allocation and collection was closely regulated and supervised by the state, and, furthermore, set the standard for relevant local arrangements. 
Mubayaa, on the other hand, was a centrally imposed fiscal obligation based not on local data but on the registers of Istanbul's central grain market (Kapan) and whose "procedure for ... local distribution was vaguely defined" (Ağir 2013: 575). As a result, it was not as dependent as avarız and nüzül on the input of the central Ottoman bureaucracy. Instead, it was local elites who played a crucial part in its carrying out (Güran 1984-1985: 30, 33; Ağir 2013: 579-580). Even the state-appointed agents for the collection of mubayaa, the mubayaacıs, often were of provincial origin and resided in Thessaloniki, which was the seat of the governor of the province (sancak) to which the district of Veroia belonged. ${ }^{34}$ Thus, there was more room for the local actors to arrange the distribution of this levy in the way that they saw fit. Given the economic inequality between the wealthy çiftlik holders and the constantly decreasing number of independent farmers in Veroia, it is only reasonable to assume that the power of the former set the pace for any negotiation with the state agents. Thus, we may claim that the compilation of tevzi registers for mubayaa was entirely the subject of negotiation among provincial actors, namely the local landed elite and the mubayaacıs.

\section{The Proliferation of Çiftliks in the District of Veroia: the Case of the Sarıcazade Family}

One of the major landholding families in eighteenth-century Veroia was the Sarıcazades. Its members whose landholding we can follow are Sarıca Ali, active in Veroia's public life as early as the late seventeenth century, his son el-Hac Mehmed Ağa, and his grandsons Ramiz Mehmed Efendi, a müderris, and Ali Efendi. ${ }^{35}$ Another family member, es-Seyyid Yahya Molla (or Bey), might have been Sarıca Ali's greatgrandson, while we may hypothesise that a woman named Ümm-i Külsum was also somehow related to the family. The Saricazades were not only landholders but also high-profile public figures. Mehmed Ağa was acknowledged as the official ayan (reis- $i$ ayan) of Veroia in 1746, while Yahya Bey was cited as "vilâyet muhtarı" in a buyruldu of $1787 .{ }^{36}$ In the 1740s and 1750s, the citing of the name of Mehmed Ağa in documents concerning affairs of public interest was often preceded by titles which honoured his high social standing: for instance, "support of the most illustrious and the notables ... prosperous" (umdet-i emacid vü'l-ayan ... saadetlü) in 1747; "pride of his peers" (fahrü'lakran) in $1759 .{ }^{37}$ On his part, Ramiz Mehmed Efendi was involved in a violent incident between local ayan factions which revolved around the office of voyvoda and shook Veroia in 1758-1759. As a result of his involvement, Ramiz Mehmed Efendi fled Veroia, while the state issued an order that he be detained in Cyprus (Anastasopoulos 2002).

The case of the Saricazades allows us to better understand, on the one hand, the usefulness of tevzi registers for the study of chiftlicisation and, on the other, the practices that we have discussed in the first part of the article. More importantly, it helps us to realise the extent of control that a small number of elite families exerted over rural land in the district of Veroia in the course of the eighteenth century, as well as to infer (for lack of comprehensive hard data) the importance of landholding as a source of revenue and power for such families.

The first person who can be readily identified as a member of this notable family through the tevzi registers of Veroia is Sarıcazade el-Hac Mehmed Ağa whose name is recorded in this form in a register dating from $1736 .^{38}$ Sadly, part of this register is missing, therefore we cannot say with certainty if Mehmed Ağa possessed land in more 
than the eight villages in which tax shares were recorded in his name. These villages are Branyat (mod. Nea Nikomedeia), Tağramon (mod. Tagarochori), Lıkoviçista (mod. Palaia Likogianni), Monoşpita (mod. Monospita), Radâni (mod. Ryakia), Alabori (mod. Prasinada), Milova (mod. Megali Gefyra) and Tirhalep (mod. Trikala). ${ }^{39}$ In four of them he appeared to be the only landholder (Fig. 5).

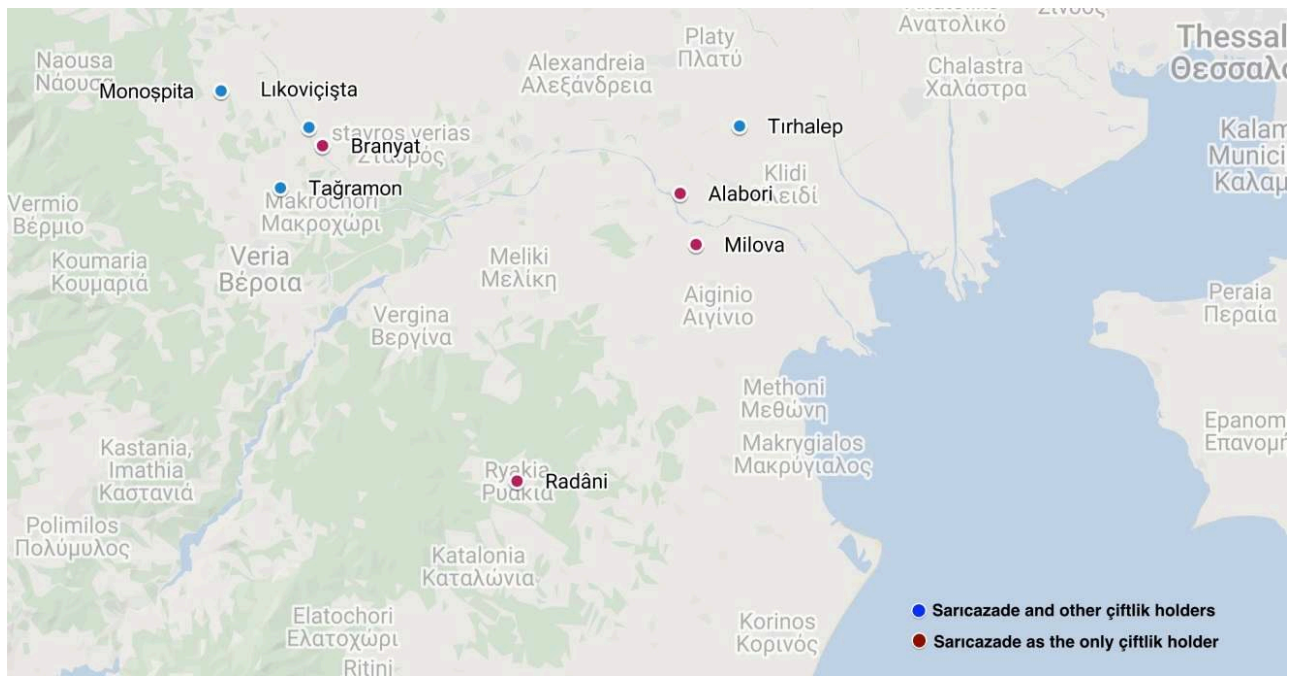

FIgURE 5: Sarıcazade el-Hac Mehmed Ağa's çiftliks in 1736 according to KKS-GR 67/6-8, 15 Safer 1149 / 25 June 1736.

(Map data (2019 Google)

The data of the tevzi register of 1736 allow us to conclude that the Mehmed Ağa who held land in the villages of Monoşpita, Milova, and Tirhalep according to a tevzi register of 1735, was in fact Sarıazade el-Hac Mehmed Ağa. ${ }^{40}$ A little earlier, in late 1732, his landholding was restricted to only Monoşpita and Tirhalep. ${ }^{41}$ Therefore, we can assume that it was at roughly that time that Mehmed Ağa intensified his involvement in landownership. Some of the eight villages in which he held land in 1736 had been transformed into çiftlik properties before his time. For instance, in Branyat there were three other landholders as early as 1704: Ali Ağa, to whom were attributed nine of the 14 hanes of the village, Yusufzade Ahmed, and İmam Mehmed Efendi. ${ }^{42}$ El-Hac Ali Ağa, who may be identified with Ali Çelebi, ${ }^{43}$ was still the biggest among three çiftlik holders in the village in 1735 , and six out of its 7.33 hanes were attributed to him. ${ }^{44}$ However, as noted above, in 1736, Mehmed Ağa appears as the only landowner in Branyat. At the exact same time that el-Hac Ali Ağa's name disappears from Branyat, Ali Çelebi's name also ceases to be recorded in Tağramon, Lıkoviçişta, and Monoşpita.

According to a kadı register entry of 1759, Sarıcazade el-Hac Mehmed Ağa resided in the neighbourhood of Câmi-i Cedid in the town of Veroia and was the son of Ali Ağa. ${ }^{45}$ Combining this piece of information with the data of the tevzi registers, we could suggest that el-Hac Ali Ağa or Ali Çelebi was the father of Mehmed Ağa and that the latter inherited his çiftliks in Branyat, Tağramon, Lıkoviçişta, and Monoşpita from the former. In fact, the name 'Sarıca Ali' appears in a kadı register entry of 1699 as that of an ayan of Veroia (Vasdravellis 1954: 107). Apparently, the Sarıcazade family had been influential since at least the late seventeenth century with Ali possibly being its founder, if we accept that 'Sarıca', which stuck with the family, described his own personal professional identity, a man of military background and reaya origin (Inalcik 1980: 292-297; Aksan 2007: 56-57). 

Mehmed Ağa and a certain Ahmed Ağa was Radâni. The two of them also held a çiftlik in Tirhalep, obtaining the tax share which in the previous year had been allocated to the local reaya. ${ }^{47}$ Milova, which was registered as a çiftlik of Mehmed Ağa in 1736, was held by Ahmed Ağa in 1727. Furthermore, Ahmed Ağa jointly held çiftliks with a certain İbrahim Ağa in the villages of Tırhovişta (mod. Kampochori), Tağramon, and Mikroğuz (mod. Makrochori). Mehmed Ağa also owned çiftliks in these three villages in $1742 .{ }^{48}$ On his part, İbrahim Ağa held some mezraas together with Mehmed Ağa in 1742 and, on his own, çiftliks in the villages or mezraas of Yavorniça (mod. Trilofo), Uhtumon, Flurya, and Vulçista (mod. Livadi) in 1742 and/or 1746; ${ }^{49}$ in this case too, Mehmed Ağa owned çiftliks in these villages or mezraas in $1748 .^{50}$ It is reasonable to assume that in cases like this, a relationship must have existed between the elite persons who jointly or separately had tax shares registered in their names in the same villages. This relationship might have been one of co-operation or antagonism, or it might have gone through both stages over the years. Two kadı register entries from 1746 show Ahmed Ağa accusing Mehmed Ağa and İbrahim Ağa of contesting his rights over or creating problems in villages under his control. ${ }^{51}$

34 According to a tevzi register for masarif-i vilâyet from 1746, Mehmed Ağa held çiftliks in 17 villages, which, in comparison with 1736, did not include Tağramon and Monoşpita. ${ }^{52}$ In the case of Monoşpita at least, this omission must be attributed to the methodology of compilation of the register, and not to withdrawal of Mehmed Ağa from it, since this village re-appears as part of his çiftliks from 1748 onwards. In any case, it is to be noted that in this instance, Mehmed Ağa was one of only three landholders whose çiftliks were listed separately from the rest, i.e., not in the list of çiftliks of the register (çiftlikân), but bundled together before their names (e.g., çiftlikân-ı el-Hac Mehmed Ağa). ${ }^{53}$ This is the first instance in which we encounter çiftlikân/emlâk/ alâka items as discussed above. In 1758, in a further stage of this practice, the names of the villages in which Mehmed Ağa held çiftliks were no longer listed. What was registered was only the grand total of their tax share with the note that it corresponded to the share of Mehmed Ağa (alâka-ı Sarıcazade devletlû el-Hac Mehmed A $\breve{a}$ ).${ }^{54}$ The transformation from a tax-allocation system centred on villages to one centred on landholders as a result of the expansion of çiftliks was reaching its completion by then.

In the mid-1740s, Mehmed Ağa was the biggest çiftlik holder in Veroia by a wide margin. The three biggest landholders in 1746-Mehmed Ağa, Abdülhalim Efendi, and Abdi Ağa -held çiftliks to which was allocated almost one-third of the tax burden of this category of villages (çiftlikân, 147 out of a total of 450 haymanes). The share of the çiftliks of Mehmed Ağa alone corresponded to more than one-fifth of the total (98 out of 450 haymanes). Furthermore, the tax share of the çiftliks of Mehmed Ağa in the category of Menlikân chiftlicised villages amounted to 50 per cent of the total of this group of 
villages (10 out of 20.25 rakams), while he also held the sole çiftlik in the Tuzcuyan group of villages. The situation was more or less the same in 1747: Mehmed Ağa's çiftliks were charged with 102 out of a total of 462 haymanes in the çiftlikân group (followed by Abdülhalim Efendi's çiftliks with 35 haymanes and Abdi Ağa's çiftliks with 24). Mehmed Ağa's tax share in the çiftlik villages of the Menlikân group was increased to 12.25 rakams out of a total of 20.25, while the situation was stable in regard to his çiftlik in the Tuzcuyan group of villages. Mehmed Ağa held çiftliks in the same 17 villages as in 1746 . 55

As early as that, the family's landholdings were not limited to those of Mehmed Ağa. One of his two sons, Ramiz Mehmed Efendi, held one çiftlik (of a tax share of only one haymane) in the previously non-chiftlicised village of Horanoz (mod. Nea Chrani) in 1746. In the summer of that same year he bought the lands (mülk and miri) of 14 Christians in the village of Rabsomanik (mod. Rapsomaniki) that had already been partly chiftlicised. ${ }^{56}$ Thus, in 1747 he became the biggest among the three çiftlik holders in the village. ${ }^{57}$ According to a tevzi register for masarif-i vilâyet from 1748, Ramiz Mehmed Efendi also held a çiftlik in şehr Altı (on the outskirts of the town of Veroia), another in the village of Servihor (mod. Palaio Zervochori) together with his brother Ali Efendi, and, finally, one more together with Çavuşzade es-Seyyid Mustafa Ağaanother major landholder of this period-in Servihor-1 Cedid (mod. Ano Zervochori). These five çiftliks (in Horanoz, Rabsomanik, şehr Altı, Servihor, and Servihor-1 Cedid) were new acquisitions, as Mehmed Ağa does not seem to have ever owned land in these localities. As for the pre-existing çiftliks of Mehmed Ağa, they were recorded in the tevzi register of 1748 in the çiftlikân / emlâk / alâka format (here, emlâk), but this time they were divided into two: one part, the smaller, as properties of Mehmed Ağa and the other, the bigger, as holdings "of his son Ramiz Mehmed Efendi and his brother Ali Efendi in partnership (iştirak)" ${ }^{58}$ The çiftliks of Ramiz Mehmed Efendi and Ali Efendi represented by far the largest tax share among çiftliks, counted in rü'us in this register: 164 out of a total of 892.75 shares for the villages of the çiftlikân group. Together with the 95.5 shares which fell to the çiftliks of their father, the Sarıcazade family's tax share represented close to one-third of the total for çiftliks, while their lands were dispersed over 24 villages. ${ }^{59}$ In half of them the Sarıcazades were the only çiftlik holders (Fig. 6). The other major çiftlik holders lagged far behind: Abdi Ağa had 67 rü'us attributed to him, Abdülhalim Efendi 37.5, Çavuşzade Mustafa Ağa 28. 


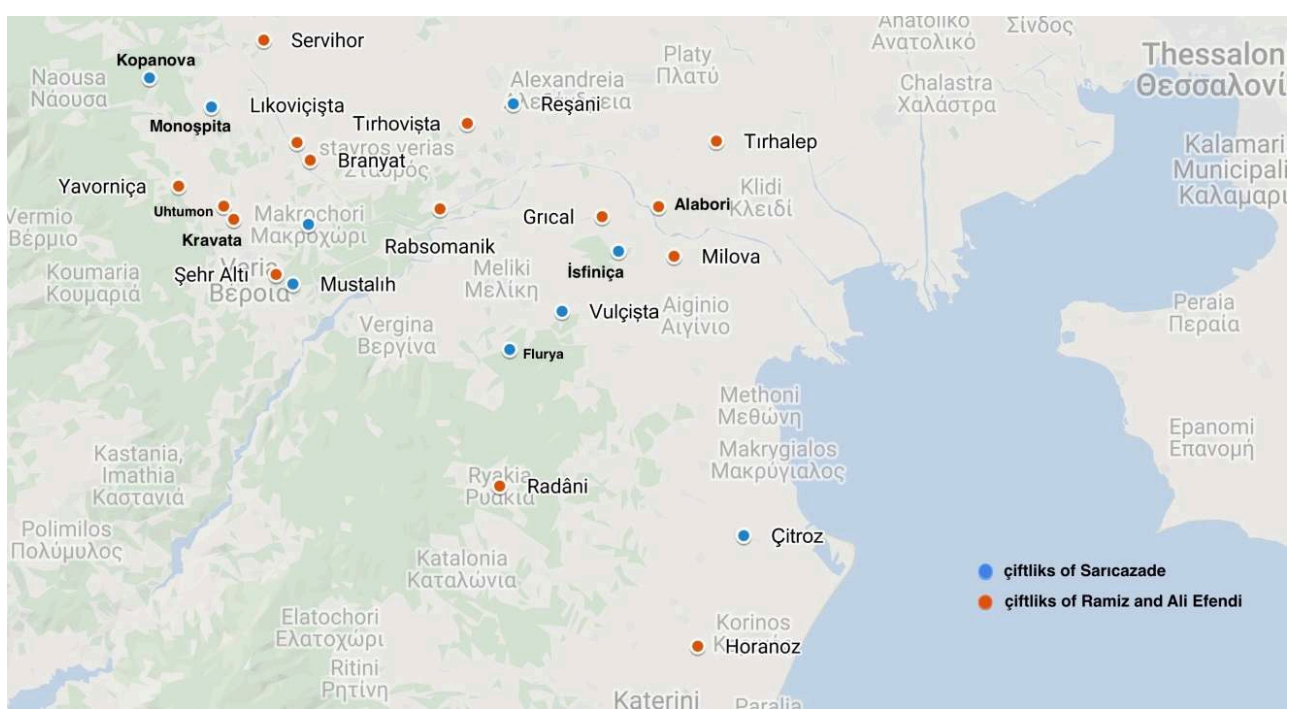

FıgURE 6: The çiftliks of Sarıcazade el-Hac Mehmed Ağa, Ramiz Mehmed Efendi, and Ali Efendi in 1748 according to KKS-GR 72/127-130, 11-20 Receb 1161 / 7 July 1748.

(Map data (C2019 Google)

In the years which followed, the Sarıcazades continued to expand their çiftliks all over the kaza of Veroia, including the south towards the town of Katerini (Ott. Katerin), seat of the powerful voyvoda of the kaza of Platamona Arnavud Hasan and his sons Halil and Mehmed: in the 1750s Uskutrina (mod. Elatochori) and İnekasrı (mod. Neokastro) became çiftliks of Ramiz Mehmed Efendi and the previously non-chiftlicised villages of Ritinyani (mod. Ritini), Braza (south of Ritini), Viromeri (mod. Kallithea), and Kastanya (mod. Kastania) were added to Mehmed Ağa's list of çiftliks. ${ }^{60}$ Furthermore, Ali Efendi, the other son of Mehmed Ağa, turned into a çiftlik Koçka (near mod. Rachia), a village belonging to the Sultanic hasses. ${ }^{61}$ Ramiz Mehmed Efendi was much more active than his brother in this chiftlicisation drive, as most villages are recorded in his name. Sometimes, the name of Ali Efendi appears next to that of Ramiz Mehmed Efendi, and in other cases the latter owns çiftliks together with other ayan or, in the village of Alabori, with Ümm-i Külsum, presumably a female member of the family. ${ }^{62}$ In fact, the 1750s saw the peak of the family's economic power. In 1759, the Saricazades possessed estates in 30 villages all over the district of Veroia. ${ }^{63}$ This means that they were present in almost one-third of the villages of the entire kaza (Fig. 7). The fiscal share of their çiftliks amounted to 253 rü'us out of a total of 1,550 for all the villages of the kaza of Veroia, ${ }^{64}$ or 246 çifts out of a total of $1,623.5,{ }^{65}$ that is, more than 15 per cent of the grand total. If we subtract the tax share of the 'independent' villages, which amounted to 41 per cent of the total (659 çifts), ${ }^{66}$ the tax share that fell to the çiftliks of the Sarıcazades represented 25.5 per cent of the share of all çiftlik landholders, a figure which suggests that investment in landholding must have figured largely in the public profile of the family, which by that time had a stable presence of several decades in chiftlicisation. Not only that, but it must have also contributed a significant part of their income, which, in a way typical of eighteenth-century provincial notables (Anastasopoulos 2015; Yaycioglu 2016: 65-115), came, as noted above, from a varied portfolio of investments. For instance, both Mehmed Ağa and Yahya Bey were involved in the collection of cizye. ${ }^{67}$ 


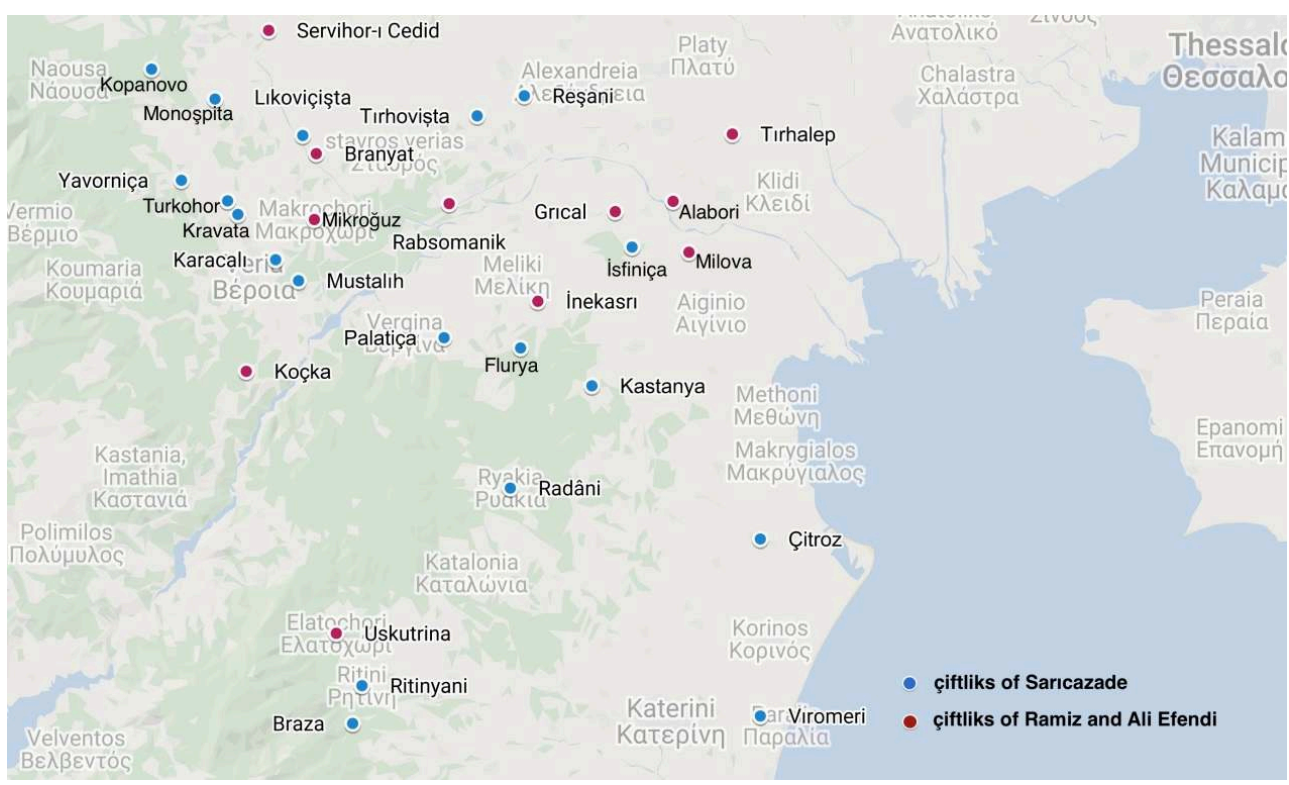

FıgURE 7: The çiftliks of Sarıcazade el-Hac Mehmed Ağa, Ramiz Mehmed Efendi, and Ali Efendi in 1759 according to KKS-GR 81/387-388, 15 Şevval 1172 / 11 June 1759.

(Map data (C2019 Google)

The peak of the Sarıcazades' çiftlik-holding coincided with the time when Ramiz Mehmed Efendi participated in the incident of 1758-1759 between rival ayan factions. ${ }^{68}$ In 1760 he was reported dead, but according to another source, he was still alive in 1761; he was definitely dead in $1768 .{ }^{69}$ Nevertheless, çiftliks continued to be registered in his name until the end of the 1760s, but their tax share diminished at a steady pace, down from 8.5 per cent of the total share of the villages of Veroia in 1759 to 7.1 per cent in 1762, 6.3 per cent in $1765,3.7$ per cent in 1770, and 3.35 per cent in 1771 (as Ramizefendizade, as a result, apparently, of his death). ${ }^{70}$ Furthermore, the Saricazade family no longer held an estate in Viromeri, near Katerini; the village had become an exclusive çiftlik of Hasan Ağa of Katerini. The latter and his sons were expanding their landholding and were to become the biggest landholders in Veroia, displacing the Sarıcazades. In 1762, the Sarıcazade family still retained land in 30 villages, and the tax share of their çiftliks amounted to 14 per cent of the total value of communal expenses. ${ }^{71}$ Hasan Ağa owned çiftliks in nine villages, located mostly near Katerini, but their tax share represented 10.5 per cent of the total. Other important landholding families, namely the families of Eminzade Ali Ağa, possibly the son or other close relative of Abdi Ağa, as noted above, and Rüşdi Ali Efendi, the son of Abdülhalim Efendi, trailed far behind with shares of 2.5 per cent or less in the total amount. ${ }^{72}$ By 1765, Hasan Ağa had taken possession of Ritinyani and Braza, villages lying nearer to Katerini than to Veroia and previously controlled by the Sarıcazades, and the tax share of his çiftliks rose to 12.2 per cent, surpassing that of the çiftliks of the Sarıcazades, which fell to 11.3 per cent of the total. ${ }^{73}$ Furthermore, the çiftlik of the Sarıcazades in Çitroz, to the north of Katerini, disappeared from the tevzi registers, and a çiftlik of Hasan Ağa made its appearance as of $1766 .^{74}$

After the death of Ramiz Mehmed Efendi, his çiftliks in Rabsomanik and Uskutrina were transferred to a 'kadıncık', presumably either Ümm-i Külsum, who had inherited his çiftlik in Alabori, or other womenfolk of the Sarıcazade family, while his land in Tırhaleb was registered as a çiftlik of his brother Ali Efendi. The Sarıcazades still held 
çiftliks in 23 villages, where usually the çiftliks of others existed too, while Hasan Ağa owned thirteen villages, where he usually was the sole çiftlik holder. The tax share of the çiftliks of the Sarıcazades fell further to 9.6 per cent of the total amount, while that of the çiftliks of Hasan Ağa increased to 15.4 per cent. ${ }^{75}$ The trend continued to be downhill for Ali Efendi: by 1777 the tax share of his çiftliks had fallen to 6 per cent of the total, and he was surpassed not only by the sons of Hasan Ağa, Halil and Mehmed, who held çiftliks whose tax shares represented 15.5 per cent of the total, but also Rüşdi Ali Efendi, whose çiftliks were allocated 7.3 per cent of the total tax burden. ${ }^{76}$ As for 1780 , the share of the çiftliks of Ali Efendi fell to 4.1 percent, while that of the sons of Hasan Ağa kept increasing and reached 20 per cent of the total. ${ }^{77}$

Despite their decreasing share, the Sarıcazades remained third in rank among çiftlik holders after Hasanağazade Halil and Mehmed, and Rüşdi Ali Efendi. ${ }^{78}$ From 1783 onwards, the name 'Yahya Bey' or 'es-Seyyid Yahya Molla' replaced that of Ali Efendi in the alâka-style entries for the çiftliks of the Sarıcazade family; the names of both were recorded with the same number of re's: 29. The only exception were the family's çiftliks in Koçka and Aya Marin which had never been included in the alâka of Ali Efendi but were always listed separately. These two continued to be entered in the tevzi registers in the name of Ali Efendi even after his alâka was transferred to Yahya. Most probably, it was not incidental that these two seem to have been among the first çiftliks that Ali had acquired more than two decades earlier. ${ }^{79}$ The tevzi registers do not provide more information on Yahya Molla, but we know from other kadı register entries that he was a Sarıcazade (Çatal 2012: 60, 344). Since he succeeded Ali Efendi in his çiftliks, we may assume that he was his son or another close relative.

In 1795, Yahya Molla (as Yahya Bey) was still the third biggest çiftlik holder after the Hasanağazades and the voyvoda of Veroia Abdurrahman Bey, but his share still was very small in comparison to those of the other two: the tax share of the çiftliks of the Hasanağazades represented 39.5 per cent of the total, the tax share of the çiftliks of Abdurrahman Bey was at 16.1 per cent, while the share of those of Yahya Bey stood at only 4.8 per cent of the total. ${ }^{80}$ By 1802 , his share had been further reduced to 4.06 per cent of the total and he ranked only eighth among the biggest landholders in the district of Veroia (Chart 4). ${ }^{81}$ 
Chart 4: Tax shares of the major landholders of Veroia in the eighteenth century according to tevzi registers.

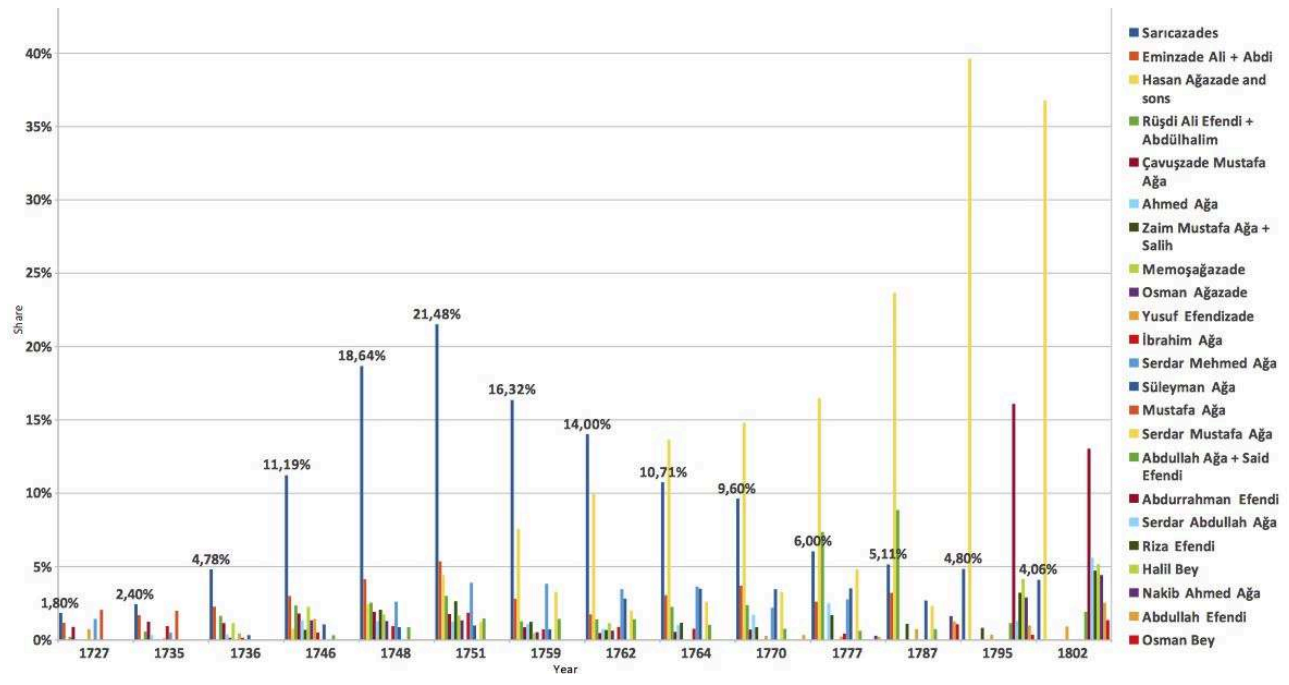

\section{Conclusion}

To sum up, our discussion of the historical evolution of the Veroia tevzi registers for avarı/nüzül, masarif-i vilayet, and mubayaa in the first part of the article complicates claims that "the various tawzi ${ }^{t}$ defteris differed only in their content; in their arrangement they were the same" (Inalc1k 1980: 335), and provides a more nuanced picture that may be described as sandwich-like: from uniformity to complexity to uniformity again. Until the end of the seventeenth century, the entire system of taxquota allocation-be it connected to centrally or locally imposed taxes and levies-was characterised by homogeneity, organised on the premise that contributions were to be collected mainly from independent farmers on the basis of the avariz/nüzül hane. From the end of the seventeenth century until the early years of the second half of the eighteenth century, however, an elaborate process of recalibrating this system began with an eye to incorporating the dynamic expansion of çiftliks as a form of landholding which had a great impact on rural economy and local politics. This process involved much experimentation and was characterised by great complexity, as new categories, entries, sub-divisions, and units were employed to describe the prevalent proprietary and labour conditions in the district of Veroia. Even if the commencement of this readjustment was related to state taxes and may have been conditioned by the centrally imposed terms of their collection, by the second half of the eighteenth century, expanding chiftlicisation in combination with the localisation of provincial administration and "the aging of the tax-house system" (McGowan 1981: 106) brought the local landholding elite to a position where they could control the process of allocation of both local and imperial taxes and other levies. During the third and last phase, we witness an effort towards re-homogenisation of the tax-allocation system. However, the crucial difference between this and the first phase is that through this process the entire system was adapted to the needs and interests of çiftlik owners. In this context, the 'independent' village was discarded as a fiscal category with the çiftlik becoming the only gauge for tax assessment. 
The case of the Saricazade family, which is discussed in the second part of the article, shows in more concrete terms how chiftlicisation was recorded in the tevzi registers of Veroia, but also provides insights into the trajectory and strategy of one of the major landholding families of the district. It seems that a family of military and reaya origin invested heavily in landholding, which must have been a sign of and, at the same time, a springboard for further upward social mobility. The Sarıcazades, who were associated with other local elite families in various ways, reached around the middle of the eighteenth century a point where they held çiftliks in almost one third of the total number of villages of the district of Veroia. However, the data of the tevzi registers suggest that from the 1760s onwards, the number and economic importance of their landholdings decreased, and this downward trend continued until the end of the eighteenth century. Thus, by the 1780s, the Saricazades were still among the biggest landholders in Veroia, but the economic weight of their property (as depicted in their tax share) was nothing to compare with what it had been in the 1750s; by 1800, their importance as landholders had decreased even further. Evidence is fragmentary, but we could suggest that the unfortunate involvement of Ramiz Mehmed Efendi in the incident of 1758-1759, as well as the aggressive policy of Hasan Ağa of Katerini and his sons with regard to the expansion of their çiftliks, especially in the south-eastern part of the district of Veroia, were two factors which contributed to the contraction of the landholdings of the Saricazades.

On a wider plane, the tevzi registers show that a small number of local or localised families, usually not more than three or four, controlled, especially in the second half of the eighteenth century, a large number of villages, possibly one in two or even more. As discussed in the introduction of this article, the withdrawal of the central state from the provinces in the course of that century, together with the political and financial opportunities which the extensive application of tax-farming created for provincial Muslim elites (Salzmann 1993), ${ }^{82}$ facilitated the rise of provincial elites such as the Sarıcazades.

\section{Archival sources}

Greek General State Archives - Archives of the Prefecture of Imathia, Veroia, Greece - Ottoman Archive, Registers of the kadı court of Veroia

Volumes no. 39, 43, 44, 53, 57, 60, 62, 63, 65, 66, 67, 70, 72, 74, 75, 80, 81, 82, 84, 85, 87, 91, 95, 97, 98, 99, 101.

(Marked as KKS-GR in footnotes and captions; the first number cited represents volume number, the second one page number)

T.C. Cumhurbaşkanlığı Devlet Arşivleri Başkanlığı - Osmanlı Arşivi, Istanbul, Turkey

- MşH.şSC.d. (Meşihat şer'iyye Sicil Defterleri)

49 Volumes no. 1090, 1091, 1092.

(Marked as KKS-TRa in footnotes and captions; the first number cited represents volume number, the second one page number)

$50 \quad$ - A.\{DVNS.AHKR.d (Rumeli Ahkâm Defterleri) 
51

. 24.

(Marked as Rumeli Ahkâm Defterleri in footnotes; the first number cited represents volume number, the second one entry number)

Türkiye Diyanet Vakfı İslâm Araştırmaları Merkezi (ISAM), Istanbul, Turkey Kadı sicilleri - Karaferye sicilleri

Volumes no. 2a (the original is kept at Ludwig-Maximilians-Universität München, Institut für Geschichte und Kultur des Nahen Orients sowie für Turkologie, Munich, Germany), 104a (the original is kept at Edremit Muzaffer Akpınar İlçe Halk Kütüphanesi, Edremit, Turkey).

(Marked as KKS-TRb in footnotes; the first number cited represents volume number, the second one folio number)

\section{Facsimiles}

Facsimile 1: A single-category tevzi register for masarif-i vilâyet recording all the villages of Veroia in a homogeneous and hane-based fashion (KKS-TRa 1088/9, 29 Şaban 1105 / 25 April 1694).

(c) T.C. Cumhurbaşkanlığı Devlet Arşivleri Başkanlığı - Osmanlı Arşivi, Istanbul, Turkey

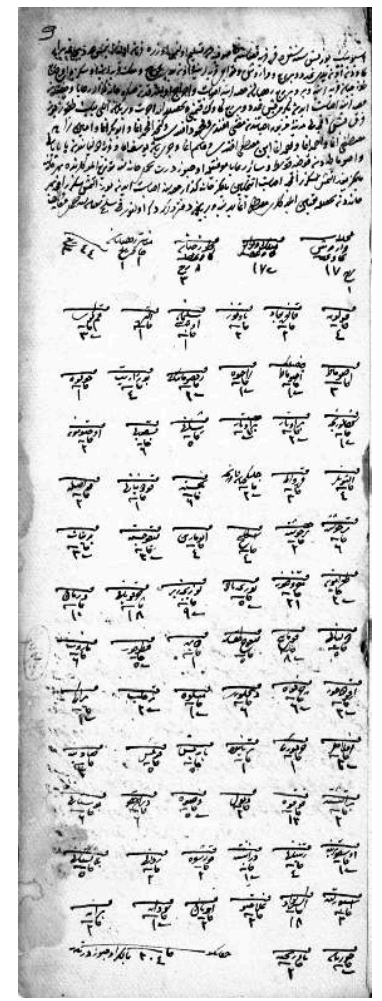

Facsimile 2: A bipartite tevzi register for masarif-i vilâyet which uses a hane-based system to record the villages of Veroia, dividing them into chiftlicised (top) and non-chiftlicised (bottom). The names of the çiftlik holders are not recorded (KKS-GR 49/51, 22 Receb 1119 / 19 October 1707).

(c) Greek General State Archives - Archives of the Prefecture of Imathia, Veroia, Greece 


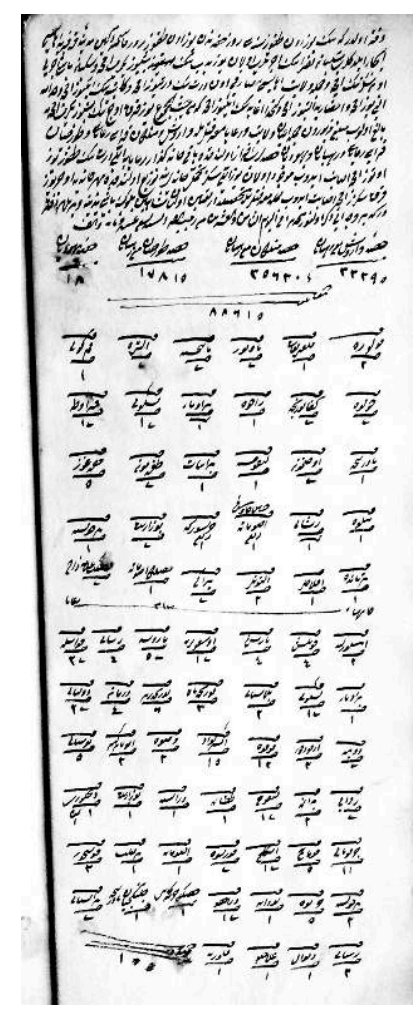

Facsimile 3: The last page of an avarı/nüzül-like tevzi register for masarif-i vilâyet in which the tax shares of the chiftlicised villages, listed together with the names of the çiftlik holders, are calculated in re's, and are followed by the lumping together of the chiftlicised villages of a handful of major landholders in the emlâk format. The tax shares of the reaya villages are calculated in hanes, while the individual villages of the Tuzcıyan, Menlikân, and havass groups-previously absent from such lists-are now listed and their shares are calculated in rakams (KKS-GR 75/56, 12 Cemaziyelevvel 1163 / 19 April 1750).

(c) Greek General State Archives - Archives of the Prefecture of Imathia, Veroia, Greece 


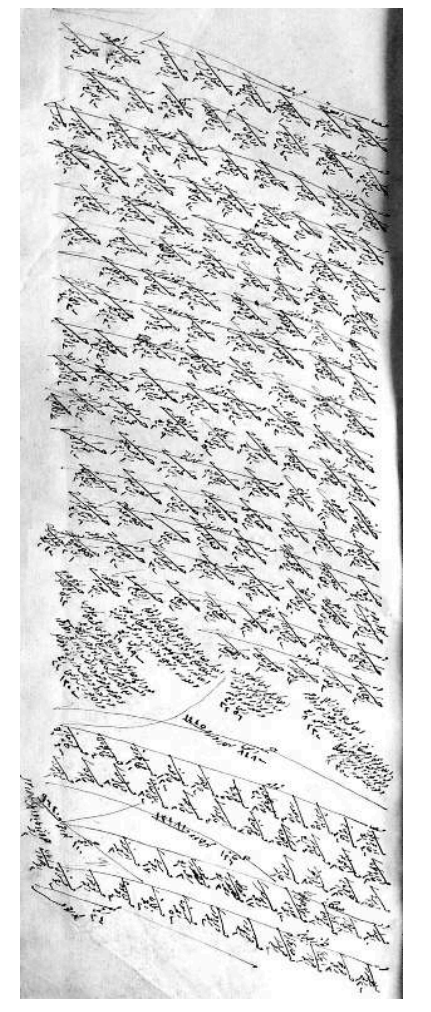

Facsimile 4: The last two pages of a tevzi register for masarif-i vilâyet listing all the villages of Veroia in a homogeneous fashion as well as the names of all the çiftlik holders. The unit used for both chiftlicised and non-chiftlicised villages is çift. The last two items represent the lumping together of a number of çiftliks under the ownership of two major landholders in the alâka format (KKS-TRb 2a/ 238v-239r, 20 Şaban 1185 / 28 November 1771).

(c) Ludwig-Maximilians-Universität München, Institut für Geschichte und Kultur des Nahen Orients sowie für Turkologie, Munich, Germany 


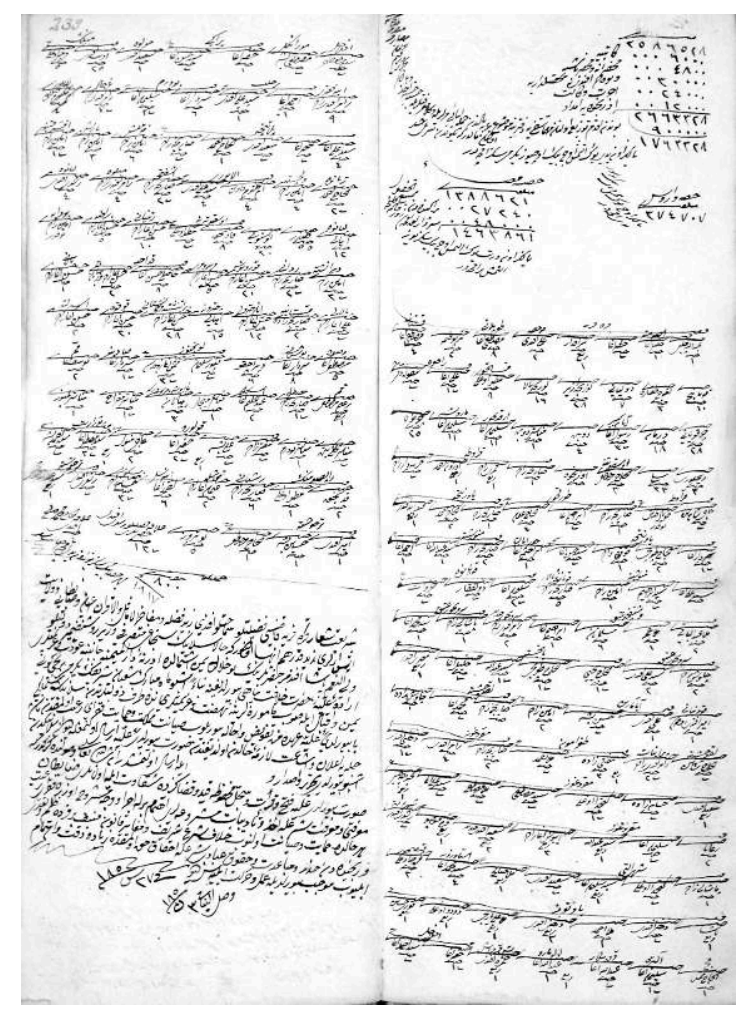

\section{Glossary}

adet-i ağnam: sheep tax

alâka: literally, claim or connection; term used to collectively denote the chiftlicised villages belonging to a particular individual

avariz: extraordinary wartime tax in cash which became regular during the seventeenth century

ayan: collective noun denoting Muslim provincial notables who served as the leaders and representatives of their districts

buyruldu: order issued by provincial governors

cizye: poll tax paid by non-Muslims

çift: 'pair of oxen', a fiscal unit

çiftlik: arable field; landed estate

emlâk: plural of mülk

ferman: Sultanic decree

güherçile: saltpetre

hane: household, a fiscal unit

hass: large sources of rural or urban income belonging to members of the Sultanic family or to high-ranking officials

havass: plural of hass

haymane: landless peasants

kadl: Islamic judge, who combined judicial, notarial, and administrative duties 
kadı sicilleri: registers of the kadı court of law containing records of the cases which the court handled and copies of incoming decrees

karye: village

kaza: judicial-administrative district over which a kadı had authority

kura: plural of karye

masarif-i vilâyet: communal expenses to be paid by the population of a district

mevkufat (kalemi): finance bureau in charge of the collection of the avarız, nüzül, and other taxes

mezraa: uninhabited, abandoned or temporarily inhabited miri arable land within or beyond the boundaries of villages

miri (land): rural land owned by the Sultan/the state

mubayaa: compulsory sale of goods to the state, especially cereals for the needs of Istanbul and the army

mubayaact: collector of mubayaa

müderris: professor at school (medrese) for the training of religious scholars

mülk (land): privately owned land

nüzül: extraordinary wartime tax, originally in kind or cash, which became regular and monetised during the seventeenth century

rakam: 'number', a fiscal unit

reaya: tax-paying Ottoman subjects

re's: 'head', a fiscal unit

rü'us: plural of re's

sürsat: compulsory sale of foodstuffs to the state

tevzi: apportionment/distribution (of tax quota)

tevzi defterleri: registers of apportionment of taxes and other communal expenses among the population of a district

vakıf: inalienable charitable endowment; when a village belonged to a vakıf, its fiscal revenue was directed to the institution supported by the vakif

vilâyet muhtarı: communal representative at the provincial level

voyvoda: tax farmer and de facto governor of a fiscal district

\section{BIBLIOGRAPHY}

Ağir, Seven (2013). 'The Evolution of Grain Policy: The Ottoman Experience,' The Journal of Interdisciplinary History 43 (4), pp. 571-598.

Aksan, Virginia H. (2007). Ottoman Wars, 1700-1870: An Empire Besieged, Harlow, Pearson Longman. 
Akyüz Orat, Jülide (2012). ‘Avârız Vergisi Üzerine Bir Çalışma: 18. Yüzyıl Başlarında Ankara Uygulamaları,' Uluslararası Sosyal Araştırmalar Dergisi 22 (5), pp. 219-232.

Anastasopoulos, Antonis (1999). Imperial Institutions and Local Communities: Ottoman Karaferye, 1758-1774, unpublished Ph.D. dissertation, Cambridge, Cambridge University Press.

Anastasopoulos, Antonis (2002). 'Lighting the Flame of Disorder: Ayan Infighting and State Intervention in Ottoman Karaferye, 1758-59,' International Journal of Turkish Studies 8 (1 \& 2), pp. 73-88.

Anastasopoulos, Antonis (2015). ‘A ‘yân,' in Georgeon, François; Vatin, Nicolas; Veinstein, Gilles; with the collaboration of Borromeo, Elisabetta (eds.), Dictionnaire de l'Empire ottoman, Paris, Fayard, pp. 137-139.

Anastasopoulos, Antonis; Gara, Eleni (2015). ‘The Rural Hinterland of Karaferye: Settlements, Divisions, and the Çiftlik Phenomenon (Seventeenth-Eighteenth Centuries), 'in Kolovos, Elias (ed.), Ottoman Rural Societies and Economies: Halcyon Days in Crete VIII. A Symposium Held in Rethymno, 13-15 January 2012, Rethymno, Crete University Press, pp. 261-291.

Anastasopoulos, Antonis; Poulios, Stefanos; Spyropoulos, Yannis (2019). 'The Spread of Çiftliks (Large Estates) in the Eighteenth-Century Ottoman Balkans: The Case of the District of Veroia,' in Rogojanu, Dumitru-Cătălin; Boda, Gherghina (eds.), Istorie, Cultură şi Cercetare III, History, Culture and Research III, Târgoviște, Cetatea de Scaun, pp. 90-109.

Aynural, Salih (2002). İstanbul Değirmenleri ve Furınları: Zahire Ticareti (1740-1840), Istanbul, Tarih Vakfı Yurt Yayınları.

Barkan, Ömer Lûtfi (1949). 'Avârız,' in İslam Ansiklopedisi, II, Istanbul, İstanbul Millî Eğitim Basımevi, pp. 13-19.

Cezar, Yavuz (1996). ‘18 ve 19. Yüzyıllarda Osmanlı Taşrasında Oluşan Yeni Malî Sektörün Mahiyet ve Büyüklüğü Üzerine,' Dünü ve Bügünüyle Toplum ve Ekonomi 9, pp. 89-143.

Cezar, Yavuz (1998). 'Comments on the Financial History of the Ottoman Provinces in the $18^{\text {th }}$ Century: A Macroanalysis,' in Essays on Ottoman Civilization: Proceedings of the XIIth Congress of the Comité international d'Études pré-ottomanes et ottomanes, Praha 1996, Archív orientální., Supplementa VIII, Prague, Academy of Sciences of the Czech Republic, Oriental Institute, pp. 85-92.

Cvetkova, Bistra A. (1959). 'Contribution à l'étude des impôts extraordinaires (avarı-1 divaniye ve tekâlif-i örfiye) en Bulgarie sous la domination turque: l'impôt "nuzul", Rocznik Orientalistyczny 23 (1), pp. 57-65.

Çakır, İbrahim Etem (2010). 'Uşak Kazâsı (1676 Tarihli Avârız Defterine Göre),' Ankara Üniversitesi Osmanlı Tarihi Araştırma ve Uygulama Merkezi Dergisi 28, pp. 27-47.

Çatal, Hazım (2012). Karaferye Kazası Hicri 1201-1202 (Miladi 1787-1788) Tarihli şer'iyye Sicili (Transkripsiyon ve İnceleme), unpublished Yüksek Lisans thesis, Izmir, Ege Üniversitesi.

Demirci, Süleyman (2010). The Functioning of Ottoman Avâriz Taxation: An Aspect of the Relationship Between Centre and Periphery. A Case Study of the Province of Karaman, 1621-1700, Istanbul, The Isis Press.

Günay, Vehbi (1993). H. 1159 (M. 1746) Tarihli Karaferye Kazası şer’iye Sicili (Transkripsiyon ve Değerlendirme), unpublished Yüksek Lisans thesis, Izmir, Ege Üniversitesi.

Güran, Tevfik (1984-1985). 'The State Role in the Grain Supply of Istanbul: The Grain Administration, 1793-1839,' International Journal of Turkish Studies 3, pp. 27-41. 
İnalc1k, Halil (1977). 'Centralization and Decentralization in Ottoman Administration,' in Naff, Thomas; Owen, Roger (eds.), Studies in Eighteenth Century Islamic History, Carbondale, Edwardsville, Southern Illinois University Press, pp. 27-52.

İnalcık, Halil (1980). 'Military and Fiscal Transformation in the Ottoman Empire, 1600-1700,' Archivum Ottomanicum 6, pp. 283-337.

İnalcık, Halil (1991). ‘The Emergence of Big Farms, Çiftliks: State, Landlords, and Tenants,' in Keyder, Çağlar; Tabak, Faruk (eds.), Landholding and Commercial Agriculture in the Middle East, Albany, State University of New York Press, pp. 17-34.

Kokdas, Irfan (2014). 'Money, Peasant Mobility, Çiftliks, and Local Politics in Salonika: 1740-1820,' Comparative Studies of South Asia, Africa and the Middle East 34, pp. 135-146.

Kotzageorgis, Phokion; Papastamatiou, Demetrios (2014). 'Wealth Accumulation in an Urban Context: The Profile of the Muslim Rich of Thessaloniki in the Eighteenth Century on the Basis of Probate Inventories,' Turkish Historical Review 5, pp. 165-199.

Kuzucu, Serhat (2016). 'XVIII. Yüzyılın İlk Yarısında Antep’te Avârız Vergisinin Uygulanışı (şeri’yye Sicillerine Göre),' Gaziantep Üniversitesi Sosyal Bilimler Enstitü Dergisi 15 (1), pp. 101-118.

Laiou, Sophia (2007). 'Some Considerations Regarding Çiftlik Formation in the Western Thessaly, Sixteenth-Nineteenth Centuries,' in Kolovos, Elias; Kotzageorgis, Phokion; Laiou, Sophia; Sariyannis, Marinos (eds.), The Ottoman Empire, the Balkans, the Greek Lands: Toward a Social and Economic History. Studies in Honor of John C. Alexander, Istanbul, The Isis Press, pp. 255-277.

McGowan, Bruce (1981). Economic Life in Ottoman Europe: Taxation, Trade and the Struggle for Land, 1600-1800, Cambridge Paris, Cambridge University Press, Éditions de la Maison des Sciences de l'Homme.

McGowan, Bruce (1994). 'The Age of the Ayans, 1699-1812,' in Inalcık, Halil; Quataert, Donald (eds.), An Economic and Social History of the Ottoman Empire, Cambridge, Cambridge University Press, pp. 637-758.

Moačanin, Nenad (2006). Town and Country on the Middle Danube, 1526-1690, Leiden Boston, Brill.

Moutafchieva, Vera P. (1988). Agrarian Relations in the Ottoman Empire in the $15^{\text {th }}$ and $16^{\text {th }}$ Centuries, Boulder, East European Monographs.

Neumann, Christoph K. (1998). ‘Selânik’te Onsekizinci Yüzyılın Sonunda Masarif-i Vilâyet Defterleri, Merkezî Hükûmet, Taşra İdaresi ve şehir Yönetimi Üçgeninde Malî İşlemler,' Tarih Enstitüsü Dergisi 16, pp. 69-97.

Neumann, Marianne Kathrin (1987/88). Die Rückwirkungen des osmanisch-russischen Krieges auf den Gerichtssprengel Qaraferya (Veroia) im Jahre 1771 (nach dem Protokollbuch des Kadiamtes), unpublished Magister thesis, Munich, Ludwig-Maximilians-Universität.

Öncel, Fatma (2017). 'Land, Tax and Power in the Ottoman Provinces: The Malikane-Mukataa of Esma Sultan in Alasonya (c.1780-1825),' Turkish Historical Review 8, pp. 54-74.

Öncel Yusufoğlu, Fatma (2018). Agrarian Relations and Estate (Çiftlik) Agriculture in Ottoman Thessaly (c. 1780-1880), unpublished PhD dissertation, Istanbul, Boğaziçi University.

Öztürk, Mustafa (1997). ‘1616 Tarihli Halep Avarız-Hane Defteri,' Ankara Üniversitesi Osmanlı Tarihi Araştırma ve Uygulama Merkezi Dergisi 8, pp. 249-293.

Papastamatiou, Demetrios (2014). 'The Structure, Content and Development of Large Estates in the Environs of Salonica during the Period 1697-1770,' in Balta, Evangelia; Salakidis, Georgios; 
Stavrides, Theoharis (eds.), Festschrift in Honor of Ioannis P. Theocharides, II, Studies on the Ottoman Empire and Turkey, Istanbul, The Isis Press, pp. 375-402.

Papastamatiou, Demetris (2017). Wealth Distribution, Social Stratification and Material Culture in an Ottoman Metropolis: Thessaloniki according to the Probate Inventories of the Muslim Court (1761-1770), Istanbul, The Isis Press.

Radušev, Evgenij (1980). 'Les dépenses locales dans l'Empire ottoman au XVIII siècle (selon les données de registres de cadi de Ruse, Vidin et Sofia),' Études Balkaniques 16 (3), pp. 74-94.

Sahillioğlu, Halil (1991). 'Avârız,' in Türkiye Diyanet Vakfi İslâm Ansiklopedisi, IV, Istanbul, Türkiye Diyanet Vakf1, pp. 108-109.

Salzmann, Ariel (1993). ‘An Ancien Régime Revisited: "Privatization" and Political Economy in the Eighteenth-Century Ottoman Empire,' Politics and Society 21 (4), pp. 393-423.

Ursinus, Michael (1980). '„Avāriz hānesi“ und „tevzi'hānesi“ in der Lokalverwaltung des Kaza Manastir (Bitola) im 17. Jh.,' Prilozi za orijentalnu filologiju 30, pp. 481-493.

Ursinus, Michael (1995). 'Hane in Kalkandelen, Rü’us in Selanik. Regionalspezifische Verwaltungspraktiken und -begriffe im Osmanischen Reich bis zum Beginn der Tanzimat,' in Majer, Hans Georg; Motika, Raoul (eds.), Türkische Wirtschafts- und Sozialgeschichte (1071-1920). Akten des IV. Internationalen Kongresses, München 1986, Wiesbaden, Harrassowitz Verlag, pp. 343-361.

Ursinus, Michael (1999). 'Natural Disasters and Tevzi: Local Tax Systems of the Post-Classical Era in Response to Flooding, Hail and Thunder,' in Zachariadou, Elizabeth A. (ed.), Natural Disasters in the Ottoman Empire. Halcyon Days III. A Symposium Held in Rethymnon, 10-12 January 1997, Rethymnon, Crete University Press, pp. 265-272.

Ursinus, Michael (2012). 'The Transformation of the Ottoman Fiscal Regime, c. 1600-1850,' in Woodhead, Christine (ed.), The Ottoman World, London New York, Routledge, pp. 423-435.

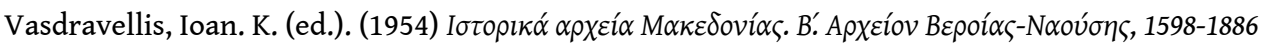
[Historical archives of Macedonia. II. Archive of Veroia-Naousa, 1598-1886], Thessaloniki, Society for Macedonian Studies.

Veinstein, Gilles (1991). ‘On the Çiftlik Debate,' in Keyder, Çağlar; Tabak, Faruk (eds.), Landholding and Commercial Agriculture in the Middle East, Albany, State University of New York Press, pp. 35-53. Yaycioglu, Ali (2016). Partners of the Empire: The Crisis of the Ottoman Order in the Age of Revolutions, Stanford, Stanford University Press.

\section{NOTES}

1. On tevzi registers, see İnalcık 1980: 335-337; Radušev 1980; McGowan 1981: 157-170; Ursinus 1995; Cezar 1996; Neumann 1998; Ursinus 1999; Ursinus 2012: 429-433.

2. Belated or no chiftlicisation may be attributed also to factors such as the villages' land and tax regime. In eighteenth-century Thessaly, the villages of the plain were transformed into çiftliks, whereas mountainous villages remained without çiftliks because they belonged to the Sultanic vakıfs (Öncel 2017: 57-58).

3. The series of tevzi registers which we have studied covers the whole eighteenth century, but has gaps in the periods 1709-1711, 1716-1719, 1752-1754, 1772-1775, 1787-1794, 1796-1798. Furthermore, we do not have tevzi registers for masarif-i vilâyet from the period 1737-1745. 
4. The adet-i ağnam also constitutes one of the most regularly collected taxes during this period, but, with the exception of one register of 1719-1720 (KKS-GR 57/823), its apportionment registers do not provide information on the çiftliks, as all villages are listed together in them with no indication whatsoever of their proprietary status.

5. On these villages see Anastasopoulos, Gara 2015: 264-265. For a comparison between the status of privileged villages recorded in the tevzi registers of different regions in the Balkans in the first half of the nineteenth century see Ursinus 1995: 358-359.

6. Until 1703, the section of the registers pertaining to chiftlicised villages is either without a heading or under the heading 'Muslim villages/households' (kura/haneha-yı Müslümanan/ehl-i Íslam). From that year on, these two options start to be used interchangeably with a third one, the heading 'kura/haneha-yı çiftlikan', which in the 1710s became the only heading placed above this section. Despite these variations, a comparison between different registers proves that they all refer to the same category of villages, i.e., chiftlicised ones. Compare, for instance, KKS-GR 43/625, 1 Zilkade 1114 / 19 March 1703 with KKS-GR 44/33-35, 5 Cemaziyelevvel 1116 / 5 October 1704.

7. This format, however, persists in other types of tevzi registers throughout the period under scrutiny, such as the sürsat, adet-i ağnam, and cizye ones. In the case of Manastır (mod. Bitola), Bruce McGowan notes that this structural change in tevzi registers occurred in 1709 (McGowan 1981: 162).

8. The hanes registered in the tevzi registers were based on the avarız hane, which during this and earlier periods represented the standard unit for the allotment of most provincial taxes in cash (Cezar 1998: 89). For an analysis of the administrative and fiscal logic behind the ratio between avarı and real households (gerçekhanes), see Barkan 1949: 14-15 and Demirci 2010: 43-94. On the interesting phenomenon of the appearance, in the province of Manastır, of local variations of the avariz hane, bearing different values from the corresponding avariz hanes recorded in centrally kept registers, see Ursinus 1980.

9. See also Akyüz Orat 2012; Kuzucu 2016. Even though these two articles concern the implementation of the avarı and nüzül taxes in Antep and Ankara in the first half of the eighteenth century, they do not discuss them in relation to their allocation through tevzi registers, but focus mainly on total numbers noted down in hanes.

10. See, for instance, KKS-GR 39/14-15, 10-20 şevval 1107 / 15-25 May 1696; 40/47-48, 2 şevval 1109 / 13 April 1698.

11. KKS-GR 44/71-74, 21 Muharrem 1116 / 25 May 1704.

12. In the tevzi registers the term 'reaya' is used for farmers who owned and cultivated their own land as opposed to those who lived and worked in farms belonging to someone else. Those belonging to the latter group were tagged haymane (for this term, see note 14 below).

13. McGowan dates some of the changes described here to 1734 (McGowan 1981: 106).

14. The term 'haymane' is to be found in the tevzi registers of Veroia from at least 1714 (KKS-GR 53/315-317, 21-29 Safer 1126 / 8-17 March 1714), although before 1735 it was used only in reference to certain groups of Muslims living in the town and on vakıf lands, but not for those tilling the land and/or herding livestock in çiftliks. Scholars usually describe haymanes as newly arrived non-registered peasants on estates that did not belong to them, such as çiftliks or timars (McGowan 1981: 106, 219; Moutafchieva 1988: 36; Moačanin 2006: 144; Kokdas 2014: 141). However, in the case of the 'independent' villages-turned-çiftliks of Veroia it is reasonable to assume that the term reflects the change in the personal status of the villagers as a result of the chiftlicisation of their lands. It is unlikely that the entire population of tens of villages fled and was replaced by peasants from elsewhere upon the chiftlicisation of their lands.

15. In fact, although the term 'çift' (pair) literally refers to a pair of oxen, its meaning may also include the house and hayloft of a peasant or even "may correspond to the potential number of sharecropper families and/or the plot of land allocated to them" (Öncel Yusufoğlu 2018: 105). As 
peasants were recorded separately from çifts in the tevzi registers of Veroia, it is obvious that the term refers only to the means of production available to them, be it just a plough team or the latter combined with a plot of land and its facilities. Here we use 'pair of oxen' as an umbrella term which may encompass any of the above-mentioned means of production, excluding human labour. For an analysis of the possible meanings of the term 'çift', see also Ursinus 1995: 350.

16. As of 1735 , the tax shares of mezraas, initially calculated simply in hanes, also started to occasionally have hanes subdivided into haymanes and çifts, possibly because of some mezraas, too, having been chiftlicised.

17. See, for instance, KKS-GR 67/8, 8 Ramazan 1148 / 22 January 1736.

18. On the various contributions paid by peasants to the owners of çiftliks see Öncel Yusufoğlu 2018: 107-116.

19. According to the confiscation records of the çiftliks of Tepedelenli Ali Paşa in Thessaly, livestock used for cultivation could belong to either the dependent peasants or the landlord (Öncel Yusufoğlu 2018: 108). If this was the case in Veroia too, then we should think of the accounting separation of the means of production from the peasants not as an accurate description of the actual situation on the ground, but as a recognition of the potential created by chiftlicisation for new combinations in property distribution within çiftliks. If it was indeed so, this practice might have served as a legitimising framework for the eventual transfer of all peasant property to the hands of landholders. It should be recalled that the ownership of such assets was indivisible and uncontested in the context of hane units.

20. KKS-GR 95/975-978, 1 Safer 1191 / 11 March 1777.

21. KKS-TRb 104a/9r-12v, 12 Cemaziyelahır 1159 / 2 July 1746. This kadı court register has been transliterated in Günay 1993.

22. The first mention of rakam units is to be found in an entry from 1724 (KKS-GR 60/66-67, 11-20 Şevval 1136 / 3-12 July 1724). This entry records 15 çiftliks in the Menlikân region, stating that they were exempt from the tekâlif taxes. According to this, one rakam equalled two çifts.

23. For the use of the term rü'us (the plural form of re's) in nineteenth-century tevzi registers from Thessaloniki see Ursinus 1995: 355.

24. Compare, for instance, KKS-GR 84/27-28, 22 şaban 1175 / 18 March 1762 with KKS-GR 84/33-34, 10 şevval 1175 / 3 May 1762. On the idea that the term çift could acquire different meanings as the bookkeeping practices of the masarif-i vilâyet registers changed see Ursinus 1995: 349-350.

25. Similar tax-unit experimentations as çiftlik property expanded and the avarız/nüzül taxes declined are to be found in other Balkan regions, too. For the district of Manastır, see McGowan 1981: 162-163.

26. Single-category tevzi registers have been excluded from all chart data, since they do not record the proprietary status of the settlements consistently.

27. KKS-GR 80/933-938, 17 Receb 1171 / 27 March 1758.

28. KKS-TRb 104a/9r-12v, 12 Cemaziyelahır 1159 / 2 July 1746; KKS-GR 72/127-130, 11-20 Receb 1161 / 7 July 1748; and KKS-GR 80/933-938, 17 Receb 1171 / 27 March 1758, respectively. Michael Ursinus translates 'sahib-i alâka' as 'landholder / landowner' (Ursinus 1995: 348).

29. KKS-GR 80/933-938, 17 Receb 1171 / 27 March 1758.

30. KKS-GR 101/20-21, 28 Zilkade 1209 / 16 June 1795; KKS-TRa 1092/59-60, 11 Rebiyülevvel 1217 / 12 July 1802.

31. KKS-GR 81/226-227, 14 Zilkade 1172 / 9 July 1759.

32. KKS-GR 75/84, 13 Ramazan 1163 / 16 August 1750.

33. For one such dispatch, the ferman and mevkufat copy accompanying it, see KKS-GR 65/796-797, 20 Zilkade 1145 / 4 May 1733.

34. See, for instance, KKS-GR 98/63, 20 Receb 1195 / 12 July 1781. 
35. In our earlier discussion of five of the most important landholders in Veroia in 1770 (Anastasopoulos et al. 2019: 108-109), we missed the fact that el-Hac Mehmed Ağa and Ramiz Mehmed Efendi were father and son. Mehmed Ağa died not long before December 1760 (KKS-GR 82/1008, 12 Cemaziyelevvel 1174 / 20 December 1760). There are conflicting reports about when Ramiz Mehmed Efendi died, but, as we discuss below in the article, it was between 1759 and 1768 . 36. KKS-GR 72/6, 9 Cemaziyelevvel 1159 / 30 May 1746; Çatal 2012: 32, 110-111.

37. KKS-GR 72/43-45, 18 Rebiyülevvel 1160 / 30 March 1747; KKS-GR 81/391, 28 şevval 1172 / 24 June 1759.

38. KKS-GR 67/6-8, 15 Safer 1149 / 25 June 1736.

39. A Mehmed Ağa, without any further specification, held land also in Ayan (mod. Ano Agios Ioannis), in the sub-district of Çitroz (mod. Kitros), together with a certain Mustafa Ağa. It is possible that this person was Sarıcazade el-Hac Mehmed Ağa.

40. KKS-GR 66/28-29, 10 Muharrem 1148 / 2 June 1735.

41. KKS-GR 65/506-509, 20 Rebiyülevvel 1145 / 10 September 1732.

42. KKS-GR 44/71-74, 21 Muharrem 1116 / 26 May 1704.

43. For example, in entries about the village Kravata (mod. Krevvatas), he was recorded as el-Hac Ali in KS-GR 63/784-785, 30 Rebiülahır 1141 / 3 November 1728, but as Ali Çelebi in KKS-GR 63/764-765, undated, but probably of the same year.

44. KKS-GR 66/28-29, 10 Muharrem 1148 / 2 June 1735.

45. KKS-GR 81/373, 22 Ramazan 1172 / 19 May 1759.

46. KKS-GR 62/1268-1279, 8 Safer 1140 / 25 September 1727. Alabori, which was a çiftlik of Mehmed Ağa in 1736, was registered as a çiftlik of a certain Mahmud Efendi in a tevzi register of 1727.

47. KKS-GR 63/784-786, 30 Ramazan 1141 / 3 November 1728.

48. KKS-GR 70/63-65, 3 Muharrem 1155 / 10 March 1742.

49. KKS-TRb 104a/9r-12v, 12 Cemaziyelahir 1159 / 2 July 1746.

50. KKS-GR 74/36-38, 11-20 Zilkade 1161 / 2-11 November 1748.

51. Günay 1993: 291-292.

52. KKS-TRb 104a/9r-12v, 12 Cemaziyelahır 1159 / 2 July 1746.

53. The same methodology applies to other registers as well from that time onwards, as we have explained above. For instance, in KKS-GR 72/127-130, 11-20 Receb 1161 / 7 July 1748, the format used is "emlâk-ı Sarıcazade el-Hac Mehmed Ağa" followed by the names of the villages.

54. KKS-GR 80/933-938, 17 Receb 1171 / 27 March 1758.

55. KKS-GR 72/43-45, 18 Rebiyülevvel 1160 / 30 March 1747.

56. Günay 1993: 135-137. The sale was recorded as “bey'-i bat-1 sahih-i şer'i ile bey’ ve temlik ve teslim" for the mülk section and as "ma'rifet-i sahib-i arz ile ... ferağ" for the miri section. Rabsomanik was registered as a non-chiftlicised village in 1727 (KKS-GR 62/1268-1279, 8 Safer 1140 / 25 September 1727). In tevzi registers of the years 1742-1746, two çiftliks (one belonging to Memoş Ağa and the other to Hristo, a Christian) were registered in the village.

57. The tax share of his çiftlik was six haymanes against three each for the çiftliks of Memoş Ağa and Hristo (KKS-GR 72/43-45, 18 Rebiyülevvel 1160 / 30 March 1747).

58. KKS-GR 72/127-130, 11-20 Receb 1161 / 7 July 1748. The çiftliks of Abdülhalim Efendi, Çavuşzade Mustafa Ağa, and Abdi Ağa were also bundled together as "emlâk-ı so-and-so" in this tevzi register. In a later tevzi register, of 1758, the çiftliks of Abdi Ağa were again registered in alâka format, but for the first time his name was accompanied by that of Eminzade Ali Ağa, possibly his son or other close relative (KKS-GR 80/481-483, 17 Receb 1171 / 27 March 1758). As of 1759 (KKS-GR 81/387-388, 15 şevval 1172 / 11 June 1759), the alâka was entered with only the name of Eminzade Ali Ağa, probably because Abdi Ağa had either died or withdrawn. In the years which followed, Ali Ağa expanded the landed property of Abdi Ağa. If our hypothesis that the two men were relatives is correct, in this case, too, the tevzi registers allow us to see how çiftliks were 
bequeathed from one generation to the next, and to confirm that landholding was a sort of family business.

59. Compare: Kotzageorgis and Papastamatiou concluded in their study of probate inventories (tereke defterleri) of the Muslim rich in Thessaloniki of the years 1700-1770 that the average number of çiftliks per person was 3.34 and that the average value of a çiftlik was 179,311.65 akçes. Furthermore, they set one million akçes as the amount beyond which one might be considered as having obtained "significant wealth accumulation" (Kotzageorgis, Papastamatiou 2014: 168, 177). We may surmise that the value of the many çiftliks of the Sarıcazades must have comfortably exceeded this threshold.

60. KKS-GR 75/79-83, 15 Zilhicce 1163 / 15 November 1750; KKS-TRb 2a/139v-141v, 21-29 şaban 1168 / 2-10 June 1755; KKS-GR 80/933-938, 17 Receb 1171 / 27 March 1758; KKS-GR 81/387-388, 15 Şevval 1172 / 11 June 1759. According to the tevzi register of 1750, Horanoz, previously a çiftlik of Ramiz Mehmed Efendi, was now registered in the name of İbrahim Ağa, a notable with whom the family shared the ownership of çiftliks, mostly in mezraas.

61. KKS-GR 80/495-497, 5 şaban 1170 / 25 April 1757.

62. After Ramiz Mehmed Efendi died or withdrew from it, the village of Alabori was recorded in tevzi registers as a çiftlik of Ümm-i Külsum and Ali Efendi and later as a çiftlik of "kadıncık", a term that probably refers to Ümm-i Külsum.

63. KKS-GR 81/387-388, 15 şevval 1172 / 11 June 1759. See also KKS-GR 81/226-227, 14 Zilkade 1172 / 9 July 1759.

64. KKS-GR 80/933-938, 17 Receb 1171 / 27 March 1758. In this tevzi register, the çiftliks of Ramiz Mehmed Efendi and Ali Efendi are listed individually, while those of their father are bundled together in the 'alâka-ı Sarıcazade' format at the end of the list.

65. The total was calculated by the scribe at 1,632 çifts but in reality it amounts to 1,623.5 (KKSGR 81/387-388, 15 şevval 1172 / 11 June 1759). The share of the Sarıcazades breaks down into 105 çifts for Mehmed Ağa, 135 for Ramiz, and six for Ali.

66. It is noteworthy that 'independent' villages paid 41 per cent of the total amount of communal expenses, while they were only 22 in number (plus two partly chifticised villages) as against 80 chiftlicised ones. This suggests that çiftlik holders may have been able to obtain (or impose) better fiscal terms for the peasants in their estates (cf. Ursinus 2012: 431; Kokdas 2014: 141; Anastasopoulos et al. 2019: 98).

67. KKS-GR 82/1008, 12 Cemaziyelevvel 1174 / 20 December 1760, cites Mehmed Ağa as "İstanbul cizyedarı-1 sabık". Yahya Bey obtained the tax farm (iltizam) of the Gypsies' cizye (kiptiyan cizyesi) of the kaza of Veroia for the year 1202 / 1787-1788 (Çatal 2012: 57, 174).

68. In 1757, the inhabitants of İksirolivad (mod. Ksirolivado), one of the few villages which were not transformed into çiftliks until the end of the eighteenth century, sent a petition to the imperial council in Istanbul accusing Ramiz Mehmed Efendi of illegally collecting an amount of money from them as their share in tax payment (KKS-GR 80/486, 21 Cemaziyelahır 1170 / 2 March 1757).

69. Rumeli Ahkâm Defterleri, 15/907, 11-20 şaban 1173 / 29 March-7 April 1760; 24/231, 21-29 Zilhicce 1181 / 9-17 May 1768.

70. KKS-GR 84/27-28, 22 şaban 1175 / 18 March 1762; KKS-GR 85/776-778, 28 Muharrem 1179 / 11 July 1765; KKS-GR 91/860-863, 15 Receb 1184 / 4 November 1770; KKS-TRb 2a/220r-221r, 1 Rebiyülevvel 1185 / 14 June 1771.

71. 164.5 rü'us out of 1,170 . A new addition to the family's çiftliks was a small çiftlik which Ali Efendi obtained in Aya Marin (mod. Agia Marina).

72. It is to be noted that, according to KKS-GR 82/1008, 12 Cemaziyelevvel 1174 / 20 December 1760, Rüşdi Ali Efendi was the son-in-law of Sarıcazade Mehmed Ağa. Apparently, the elite families of Veroia created networks through marriages and business partnerships. 
73. 117.5 çifts for the çiftliks of Hasan Ağa against 114.5 for those of the Sarıcazades out of a total of 967 çifts for the whole region (KKS-GR 85/776-778, 28 Muharrem 1179 / 11 July 1765).

74. KKS-GR 87/649-651, 3 Zilhicce 1179 / 13 May 1766.

75. KKS-GR 91/860-863, 15 Receb 1184 / 4 November 1770.

76. The share of Ali Efendi includes the çiftliks of a 'kadıncık' in Uskutrina and Rabsomanik (27.5 çifts or 1.5 per cent of the total) (KKS-GR 95/295-297, undated but it concerns the mubayaa tax of 1191/1777). Alabori no longer belonged to the Saricazade family.

77. KKS-GR 97/241-243, undated but preceded and followed by entries of $1194 / 1780$. The share of Ali Efendi includes the çiftlik of 'kadıncık' in Rabsomanik (3 rü'us or 0.3 per cent of the total).

78. Ali Efendi was recorded among the alâka landholders after the Hasanağazades and Rüşdi Efendi until 1782 (KKS-GR 98/155-156, 23 şaban 1196 / 13 August 1782).

79. KKS-TRa 1090/18-19 and 24-27, 23 Rebiülahır 1197 / 28 March 1783 and 29 Muharrem 1197 / 4 January 1783, respectively; KKS-GR 99/10-11, 11 Receb 1199 / 20 May 1785.

80. KKS-GR 101/9-12, 25 Zilhicce 1209 / 13 June 1795. Also, Ali Efendi still had a tiny share of 0.16 per cent.

81. KKS-TRa 1092/59-60, 11 Rebiyülevvel 1217 / 12 July 1802.

82. As in most provinces of the Ottoman Empire, tax-farming was an important economic activity and asset for the local Muslim elite of Veroia. This is an important topic which, nevertheless, lies outside the scope of this article.

\section{ABSTRACTS}

This article examines the spread of landed estates (çiftliks) in the rural areas of the Balkan district (kaza) of Veroia (Ott. Karaferye) in the course of the eighteenth century, and its impact on taxallocation practices. In the light of a thorough analysis of various types of registers of apportionment (tevzi defterleri) of taxes and other communal expenses among the local population, we argue that the expansion of çiftliks held by ayan to the detriment of peasant landholdings had an important impact on tax-allocation processes, which ultimately adopted the çiftlik as the standard taxpaying unit. This development reflected a new social, political, and fiscal reality that is exemplified by the case of Sarıcazade el-Hac Mehmed Ağa and his family, which is discussed in the second part of the article. As our focus is on the interconnection between investment in landed property and involvement in the tax-allocation system, we discuss and contextualise the picture that emerges from the registers of apportionment in regard to the Saricazade family's accumulation of land. In their capacities as landholders and local political actors, the Saricazades personify both the empowerment and fluidity of status and wealth of provincial elites in the eighteenth-century Ottoman Empire.

\section{INDEX}

Keywords: Ottoman Empire, Ottoman Balkans, Veroia (Karaferye), taxation, çiftliks, eighteenth century, landholding, tevzi defterleri, Sarıcazade Mehmed 


\section{AUTHORS}

\section{YANNIS SPYROPOULOS}

Institute for Mediterranean Studies/FORTH, Rethymno

spyropoulos@ims.forth.gr

\section{STEFANOS POULIOS}

University of Crete, Rethymno

stpoulios@gmail.com

\section{ANTONIS ANASTASOPOULOS}

University of Crete and Institute for Mediterranean Studies/FORTH, Rethymno

anastasopoulos@uoc.gr 